\title{
A Confirmation Bias View on Social Media Induced Polarisation During Covid-19
}

\author{
Sachin Modgil ${ }^{1} \cdot$ Rohit Kumar Singh $^{1} \cdot$ Shivam Gupta $^{2} \cdot$ Denis Dennehy $^{3}$ (I)
}

Accepted: 1 November 2021

(c) The Author(s) 2021

\begin{abstract}
Social media has played a pivotal role in polarising views on politics, climate change, and more recently, the Covid-19 pandemic. Social media induced polarisation (SMIP) poses serious challenges to society as it could enable 'digital wildfires' that can wreak havoc worldwide. While the effects of SMIP have been extensively studied, there is limited understanding of the interplay between two key components of this phenomenon: confirmation bias (reinforcing one's attitudes and beliefs) and echo chambers (i.e., hear their own voice). This paper addresses this knowledge deficit by exploring how manifestations of confirmation bias contributed to the development of 'echo chambers' at the height of the Covid-19 pandemic. Thematic analysis of data collected from 35 participants involved in supply chain information processing forms the basis of a conceptual model of SMIP and four key cross-cutting propositions emerging from the data that have implications for research and practice.
\end{abstract}

Keywords Echo Chambers $\cdot$ Social Media Induced Polarisation $\cdot$ Confirmation Bias $\cdot$ Covid-19

\section{Introduction}

Social media is increasingly being used by organisations to manage business activities and relationships among supply-chain stakeholders (Choi et al., 2020; Huang et al., 2020; Singh et al., 2018) including, new product development (Giannakis et al., 2020), service improvement (Fan \& Niu, 2016), daily sales forecasts (Cui et al., 2019), and information dissemination (Kanagarajoo et al., 2019). The prevalence and speed at which social media platforms (e.g., WeChat, Facebook, LinkedIn, Twitter, Flickr, WhatsApp) facilitate the exchange of real-time data (Gorwa \& Guilbeault, 2020; Rousidis et al., 2020) has made it a popular tool for effective supply chain management (Choi et al., 2020). For instance, throughout the supply chain, social media is being used to monitor in real-time, risks,

\footnotetext{
Shivam Gupta

Denis Dennehy

denis.dennehy@nuigalway.ie

1 International Management Institute (IMI) Kolkata, Kolkata, India

2 NEOMA Business School, Mont-Saint-Aignan, France

3 National University of Ireland Galway, Galway, Ireland
}

transactions, consumer sentiment, and purchasing decisions, as well as interact with consumers to track their behaviour (Brusset \& Teller, 2017; Havakhor et al., 2018; Min \& Zhou, 2002). Essentially, social media enables stakeholders of a supply chain to communicate and exchange information that can impact the forecasting of disruptions, order fulfilment, and production flow to match supply and demand (Grant, 2016; Rauniar et al., 2014). On one hand social media helps in communicating individuals and organizations about their products, services and developing network of communities that can be helpful to share the information on real time basis and create the awareness on a specific issue such as health during Covid-19 (Mheidly \& Fares, 2020). On the other hand, social media is full of possibilities of fake and misleading content such as Covid-19 variants and their cure along with role of vaccination in fighting Covid-19, along with cyber risks (Brummette et al., 2018; Islam et al., 2020).

The universal access to real-time information that social media provides to users (Dwivedi et al., 2018) can lead to supply chain participants becoming highly susceptible to 'confirmation bias' and 'echo chambers' e.g., situations where individuals "hear their own voice" (Bessi, 2016; Boutyline \& Willer, 2017; Brugnoli et al., 2019; Jacobson et al., 2016). The influence of echo chambers includes excluding alternate perspectives (Gillespie et al., 2014), a 
lack of common ground (Layman et al., 2006) and political, administrative, and social gridlock in many contexts (Hutchens et al., 2021; Kim \& Kim, 2019). Therefore, an approach of mindfulness and reliability needs to be developed to avoid echo chambers across the supply chain (Butler \& Gray, 2006; Dernbecher \& Beck, 2017; Thatcher et al., 2018). Hence, social media induced polarization (SMIP) can be defined as skewed opinions, information/misinformation regarding socio-cultural activities including products or services that can lead to mass destruction of property and other crisis (O'Hara \& Stevens, 2015).

The devastating effect of SMIP on communities, businesses, and governments has been identified by the World Economic Forum (2018) as the greatest threat to society due to the speed at which 'digital wildfires' spread on a global scale. Discourse on SMIP has reached mainstream media with prominent business leaders including Tim Cook (CEO, Apple) criticising polarisation and misinformation due to social media and the facilitating role that technology companies play by prioritising conspiracy theories and violent incitement because of their high rates of engagement (Reuters, 2021; Weckler, 2021). The providers as well as users are the victims of unreliable information that affect the decision making for most of the organizations.

In the context of SMIP, echo chambers refer to situations where users consume content and engage in discourse that predominantly supports the same point of view that users hold and believe themselves (Boutyline \& Willer, 2017; Flaxman et al., 2016). In the context of this study, social media can induce polarisation in the form of echo chambers in global supply chains due to regional differences in terms of selecting, filtering, and sorting of information on social media (Flaxman et al., 2016; Miroudot, 2020). For example, echo chambers can occur as a global event unfolds (i.e., Covid-19, natural disaster) whereby supply chain participants are influenced by their professional and personal experiences (Bhagwat \& Sharma, 2007; Muckstadt et al., 2001), as well as the information that is circulated and referred through social media (Gupta et al., 2021; Barberá et al., 2015; Toubiana \& Zietsma, 2017). The impact of echo chambers on supply chain decision making can lead to excessive or insufficient stock levels in regional warehouses (Sharma et al., 2020).

The ubiquitous nature and speed of social media has been attributed to its popularity as a tool to coordinate supply chain activities (Choi et al., 2020). The speed of information dissemination on social media is also highly influential as content published first tends to get more attention and it influences the opinion of end users (Roozenbeek \& van der Linden, 2019; Wang et al., 2015), as well as decision makers spread across the globe (Arnott, 2006; Wu et al., 2019). Supply chain participants are also increasingly exposed to high volumes of information and over a period they tend to favour certain social media platforms due to their familiarity with the source of information rather than its trustworthiness (Fidel \& Green, 2004; Orji et al., 2020). The choice of social media platform can significantly impact supply chains from a risk management perspective (Culp, 2020; Fu et al., 2013; O'Leary, 2011) as supply chain participants are influenced by the sentiment of posts, concerns or tweets that are expressed by customers, retailers, and other stakeholders (Clapham et al., 2019; Wuebben, 2016; Zadeh \& Sharda, 2014).

As supply chains become increasingly digitised using social media platforms and other digital technologies (i.e., AI, Big data), supply chain participants are increasingly seeking and believing the information from like-minded individuals (He et al., 2017; Sestino et al., 2020; Tim et al., 2021). This approach can increase the risk to echo chambers as participants may unknowingly seek reinforcement of existing biases and beliefs (Bhardwaj et al., 2016; Flaxman et al., 2016).

The phenomenon of 'SMIP' has been studied from different perspectives (e.g., Flaxman et al., 2016; Geschke et al., 2019; O'Hara \& Stevens, 2015; Spohr, 2017) and in varied contexts, such as politics (Kim \& Kim, 2019; Hyun, \& Moon, 2016; Yarchi et al., 2020, Lee, 2016), climate change (e.g., Fisher et al., 2013; Leviston et al., 2013), and news framing (Han \& Federico, 2018; Hyun \& Moon, 2016). Recent studies (e.g., Del Vicario et al., 2017; Sikder et al., 2020) have begun modelling the combination of bias and polarisation to examine the impact of misinformation in social media networks. There remains however, much scope to advance understanding of SMIP as there is a noticeable absence of research that focuses on the structure of social media polarisation in the context of global events such as Covid-19, where participants are highly susceptible to developing echo chambers through confirmation bias (Boutyline \& Willer, 2017; Orji et al., 2020). To this end, the aim of this study is to 'explore how manifestations of confirmation bias contribute to the development of echo chambers, in the context of supply chains during the Covid-19 pandemic.' To achieve this aim, we seek to answer the following research question: How do the elements of SMIP lead to the emergence of echo chambers in the context of supply chains?

To answer this research question, this study adopts an interpretive qualitative approach to explore SMIP from the perspective of supply chain participants by using thematic analysis to identify how four elements (e.g., environmental setting, actors, mechanism, and outcome) contribute to the development of echo chambers.

The remainder of the paper is structured as follows. A review of pertinent SMIP literature that informs our conceptualisation of echo chambers through confirmation bias is presented. Next, the research method and data collection and analysis are outlined. Then key findings and emergent 
themes are presented that form the basis of four cross-cutting propositions. Followed by a discussion, implications, and future research. The paper ends with a conclusion.

\section{Literature Review}

\subsection{Social Media Induced Polarisation}

The proliferation of social media has been a catalyst to inducing a dangerous, socio-cultural polarisation of society (Montalvo \& Reynal-Querol, 2005; Spohr, 2017; Vishwanath, 2015). This polarisation phenomenon has led researchers to explore SMIP from different theoretical lenses to study specific social media platforms and particular attention given to fake news (Langley et al., 2021; Brummette et al., 2018; Lee et al., 2015a; Shearer \& Grieco, 2019; Singh et al., 2020). Manifestations of SMIP include misinformation about presidential election campaigns (Guess et al., 2018; Linvill \& Warren, 2020; Schäfer et al., 2017), race (Jamieson, 2020), immigration (Jaramillo-Dent \& PérezRodríguez, 2021; Newman et al., 2017), religion (Said, 2008), and pandemics, specifically Covid-19 (Laato et al., 2020). The rapid global adoption of social media technology has significantly influenced many job roles and supply chain activities (Ribarsky et al., 2014; Zamani et al., 2020). Organisations are incorporating social media technology as a core capability to deliver information efficiently and cost-effectively to stakeholders in their supply chain (Osatuyi, 2013; Thatcher et al., 2018; Xie \& Lee, 2015; Zhang et al., 2017). For example, increasing its visibility in the supply chain ecosystem, facilitating real-time communication between its customers, and to mitigate risks $(\mathrm{Wu} \& \mathrm{Li}$, 2018).

Social media tools (e.g., blogs, wikis) and platforms (Facebook, Twitter, and LinkedIn etc.) are increasingly being used by consumers (individuals) and providers (organisations) to (i) post and share information, (ii) develop a network of communities, and to achieve competitive advantage in both developed and developing countries (Batrinca \& Treleaven, 2015; Obar et al., 2012; Stieglitz \& DangXuan, 2013). Essentially, social media enables individuals and organisations to act as influencers in the dissemination of information in terms of posting, re-sharing, commenting, tagging, and re-tweeting (Lee et al., 2015b; Shin \& Thorson, 2017). The dark side of this form of endorsed information sharing is that consumers of the information are exposed to 'filtered' information (Fletcher \& Nielsen, 2018; Gallaugher \& Ransbotham, 2010; Kietzmann et al., 2011; Tran et al., 2020). This exposure increases the risk of misinformation being shared across the social media platform, leading to SMIP, such as echo chambers (Brugnoli et al., 2019; Mondal et al., 2018; Toubiana \& Zietsma, 2017; Wu et al., 2019).
Therefore, individuals need to rely on mindfulness and adopt reliable technologies consuming and sharing information (Endsley, 2018). Individuals also tend to seek social media platforms that support their beliefs and attitudes, to gain confidence in their biased views (Arnott, 2006; Nikolov et al., 2019; Shin \& Thorson, 2017; Susarla et al., 2012). The fake content circulating on social media lead to extreme situations. For example, in 2019, a baby's bloodied corpse led to the violence and killed at least 10 people in Africa's Nigeria (LA Times, 2019). In another fake campaign run by secondary school students in Chile against the fare of metro, led to the developments of civil protest, violence and deaths leading to the instability for weeks in the country (Atlantic Council, 2019). Recently, people are posting the content related to Covid-19 and its vaccination impact and people are avoiding taking the vaccine, which is culminating the fear of another variant of Covid-19 and resulting into slow progress of inoculation (India Today, 2021).

The degree of SMIP is however, depends on the type of network (e.g., centralised or egalitarian) that individual consumers have joined (Juris, 2012). In a centralised network there is usually only one or a select number of individuals at the centre who play the role of 'influencer' as they can filter or block information before sharing it to a much wider network of its members (Culnan et al., 2010; Gallaugher $\&$ Ransbotham, 2010). While in an egalitarian network, all members have equal contact and influence across the network and therefore opinions can be shared by any individual within the network, and information is shared unfiltered to all members (Sikder et al., 2020). The attitude or belief system of a participant can be influenced due to the information processing approaches in both types of networks (Petty et al., 2009). When a participant is motivated and capable, they will carefully engage, reflect, and connect with pre-existing beliefs and then influence the cognitive network (Arnott, 2006). A cognitive network indicates a complex structure, where nodes signify concepts and branches specify one or more type of conceptual relationship, for instance two words describe the same sense in one context or like one another (Islam et al., 2020). The cognitive network is dependent on cognitive ability of individuals those are motivated, not motivated or lack cognitive ability may engage in peripheral processing and rely on the source of information due to its credibility that can lead to a change of attitude (Petty et al., 1987). Compared to central processing, the egalitarian network does not produce long lasting changes in belief system (Kelman, 2006).

SMIP can be witnessed in both types of networks (Centralised and Egalitarian) as partisan bias can become amplified when bias is displayed by a centralised echo chamber, while in the egalitarian echo chambers, the quality of ideas is a basis for their spread as compared to a particular individual (Chou et al., 2018). In the context 
of supply chains, participants act as 'partisan' (e.g., creator and gatekeeper of the shared information) or 'bipartisan' (e.g., consumer of the information or reshare/endorse the information) on social media platforms (Anand et al., 2007; Sharif, 2002). For example, due to national and regional lockdowns during the Covid-19 pandemic, people spent more time on social media discussing their views about the virus and vaccines (Sarkis, 2020; Islam et al., 2020; Nabity-Grover, 2020). Using social media in this way is an 'infodemic', due to the creation and consumption of misinformation related to the virus and vaccines which created confusion and distrust among people and hampered an effective response to the pandemic (Verma \& Gustafsson, 2020) and influencing the supply chains.

\subsection{Confirmation Bias}

Confirmation bias occurs, when users encounter information that reinforces their pre-existing beliefs and attitudes (Bessi, 2016; Geschke et al., 2019; Zhao et al., 2020). Confirmation bias is defined as the tendency to interpret, search for, recall, and favour the information in a way that confirms one's pre-existing beliefs or hypotheses resulting into polarised views about an issue or event (Westerwick et al., 2017; Gupta et al., 2021). Confirmation biases indicate why a group of individuals with opposing views on a topic can view the same evidence. The individuals those are victims of confirmation bias give more weightage to evidence to support their beliefs rather than undervaluing the evidence that can disprove it (Westerwick et al., 2017; Huang et al., 2012). Therefore, the tendency of people to favour the information on their prior exposure or hypotheses can be regarded as confirmation bias, which is stronger for the activities and issues those are highly emotive and deeply entrenched (Zhao et al., 2020). The information presented on social media is not only reflective of the designer's values and beliefs, which can be one-sided and/or sensational (Zhang et al., 2017; Pariser, 2011). Previous studies conclude that users generally tend to search, believe, and share information that conforms to their own beliefs and attitudes, but ignore the information that challenges their beliefs and attitudes (Itzchakov \& Van Harreveld, 2018; Knobloch-Westerwick \& Kleinman, 2012; van Strien, Kammerer et al., 2016). In the context of SMIP, social media platforms facilitate the configuration and aggregation of 'like-minded' people and network that reinforce and further empower polarised groups (Giannoccaro, 2018; Westerwick et al., 2017; Stroud, 2008).

\subsection{Echo Chambers}

Echo chambers refer to the situation where people 'hear their own voice' (Boutyline \& Willer, 2017; Flaxman et al., 2016). In the context of social media, it refers to situations where users consume content that expresses the same point of view that users hold themselves (Bessi, 2016; Geschke et al., 2019). As social media platforms largely rely on algorithms to generate large quantity of content, which can lead to the emergence of conspiracy theories, other forms of distorted information, and even extremist groups with a shared ideology, which further lead to the emergence of echo chambers (Boutyline \& Willer, 2017; Flaxman et al., 2016; Schilling \& Fang, 2014). The evolution of a group or community can be observed through the configuration of communication patterns (Tim et al., 2018). Weak patterns of communication between a group of users can be observed as compared to strong patterns of communication within the group, leading to the formation of echo chambers (Brugnoli et al., 2019). Since it is difficult to further identify the sub-groups by just analyzing the communication pattern on social media platforms, the measurement of echo chambers cannot be identified at group level as it requires the measurement of communication pattern within group as compared to between groups (Carr \& Hayes, 2015; Go \& You, 2016). However, the level of fragmentation between groups can define the degree of echo in chambers (Brugnoli et al., 2019).

The exponential growth of data creation, data flow and consumption across the spectrum of social media platforms offers many opportunities and challenges for supply chain participants (Legner et al., 2017; Sarimveis et al., 2008). On the one hand, supply chain participants are actively looking for the modes, where they can capture the precise information and improve the visibility, control, and efficiency in their supply chain (Sodhi \& Tang, 2019). On the other hand, supply chain activities are governed by participants who have their own pre-existing beliefs and attitudes that can lead to 'confirmation bias', which can negatively impact the supply chain activities (Huang et al., 2020; Huang et al., 2012; Zhao et al., 2020). Earlier studies on social media have majorly focused on identity, social power, social capital, and social loafing that led to polarisation based on individuals' attitudes, actions, and intentions for using social media (Dwivedi et al., 2018; Erkan \& Evans, 2016; O'Leary, 2011; Rauniar et al., 2014; Rim et al., 2020). Indeed, such studies have made valuable contributions to knowledge; however, they do not conceptualise how the (i) foundational elements, (ii) role of actors, and (iii) phenomena lead to the emergence of echo chambers through dominance of confirmation bias (Boulianne et al., 2020; Sasahara et al., 2020). In this study, we conceptualize how confirmation bias can illuminate elements that can contribute to the development of 'echo chambers' in the context of supply chains (see Fig. 1).

In the context of supply chains, participants include professionals, consulting firms and organisations that play an equal role in creating and sharing the information. It is therefore appropriate to view the system as 
Fig. 1 Conceptualisation of echo chambers through confirmation bias on social media

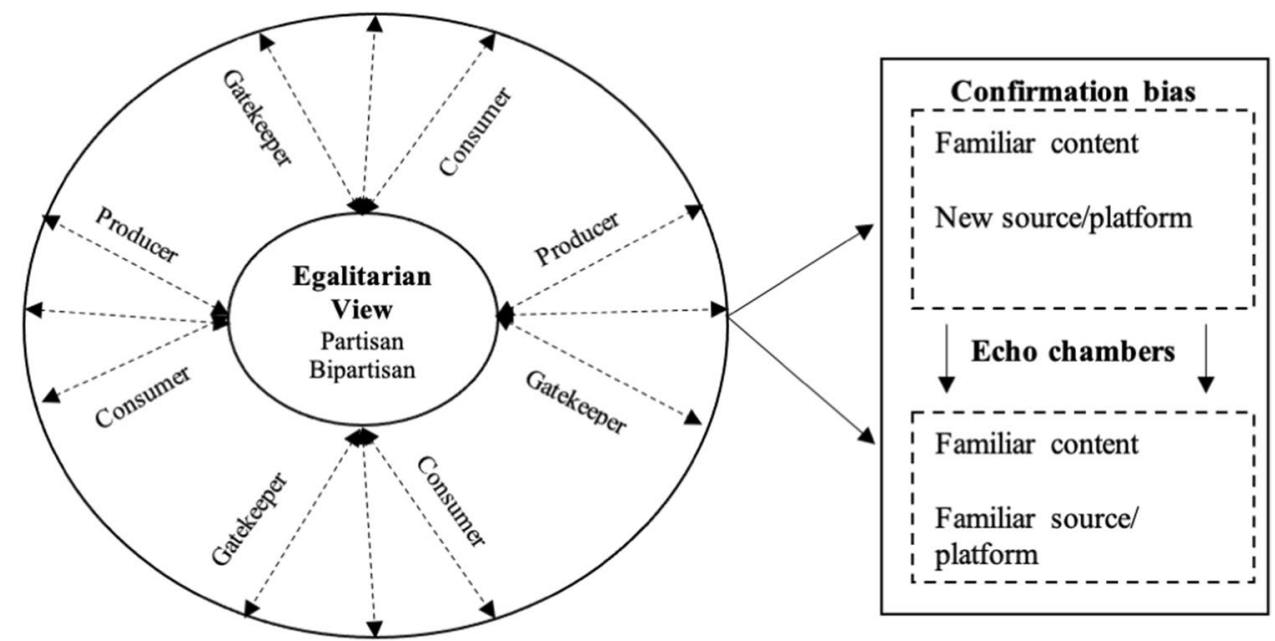

egalitarian, where partisan and bi-partisan members coexist. Partisans are the producers and users of the content with one-sided leaning, whereas bi-partisan producers create and consume the content with both side view. The gatekeeper type of users consumes the content with both perspectives but produce it with single sided leaning after some filtration. These consumers and producers represent a smaller group with higher network centrality, without much embedded in their community network. It is relatively easy to identify partisan users as compared to gatekeepers (Garimella et al., 2018). The characteristics of partisans, bi-partisans and gatekeepers leads to the development of confirmation bias, whereby content is related and familiar and posted through new source (Jacobson et al., 2016). When different users on social media consume the information from different sources, they develop the echo chambers on the premise of confirmation of their beliefs resulting into polarisation.

\section{Research Methods}

This exploratory study adopts an interpretive case study approach as it is suited to (i) understanding of the influence of context (Walsham, 1993), (ii) examining a new phenomenon that lacks empirical substantiation (Benbasat et al., 1987; Eisenhardt, 1989; Stake, 2000), and (iii) extending the theoretical underpinning of the study (Benbasat et al., 1987; Pagell \& Wu, 2009; Stuart et al., 2002). The research design (see Fig. 2) provides a clear 'chain of evidence' (Yin, 2002) with explicit links between the research questions, the data collected, and the conclusions drawn, which helps "follow the derivation of any evidence, ranging from initial research questions to ultimate case study conclusions." (Yin, 2002, p.83).

\subsection{Data Collection}

Using snowball sampling (Naderifar et al., 2017; Noy 2008), 35 supply chain practitioners with extensive industry experience and knowledge of AI were identified for the purpose of this study (see Table 1). Interviews were conducted between September and December 2020. Due to Covid-19, interviews were conducted remotely via Microsoft Teams and Zoom. The duration of interviews ranged between 30 and $50 \mathrm{~min}$. Interviews were recorded and transcribed using Otter, an AIbased transcription software, proof-read and annotated. Data saturation (Birks et al., 2013; Nelson, 2017) was achieved after 35 interviews, and therefore, no additional interviews were conducted. For the purpose of research rigour and anoymonity, a code (e.g., R1 to R35) was assigned to each interviewee.

\subsection{Data Analysis}

Data analysis was conducted using open, axial, and selective coding that further enabled us to derive themes and sub-themes through the process of iteration (Dezdar \& Sulaiman, 2009; Strauss \& Corbin 1997). Both the Glaserian and Straussian grounded theory methodologies are the most prevalent in extant literature (Matavire \& Brown, 2013). The Glaserian approach is rooted in critical and rationalistic thinking, whereas the Straussian approach is pragmatic and can identify the phenomenon through interaction among participants. A thematic analysis of the qualitative data using the Strauss \& Corbin (1997) method was adopted as it supports the development of theory based on the stories and 
Fig. 2 Research design

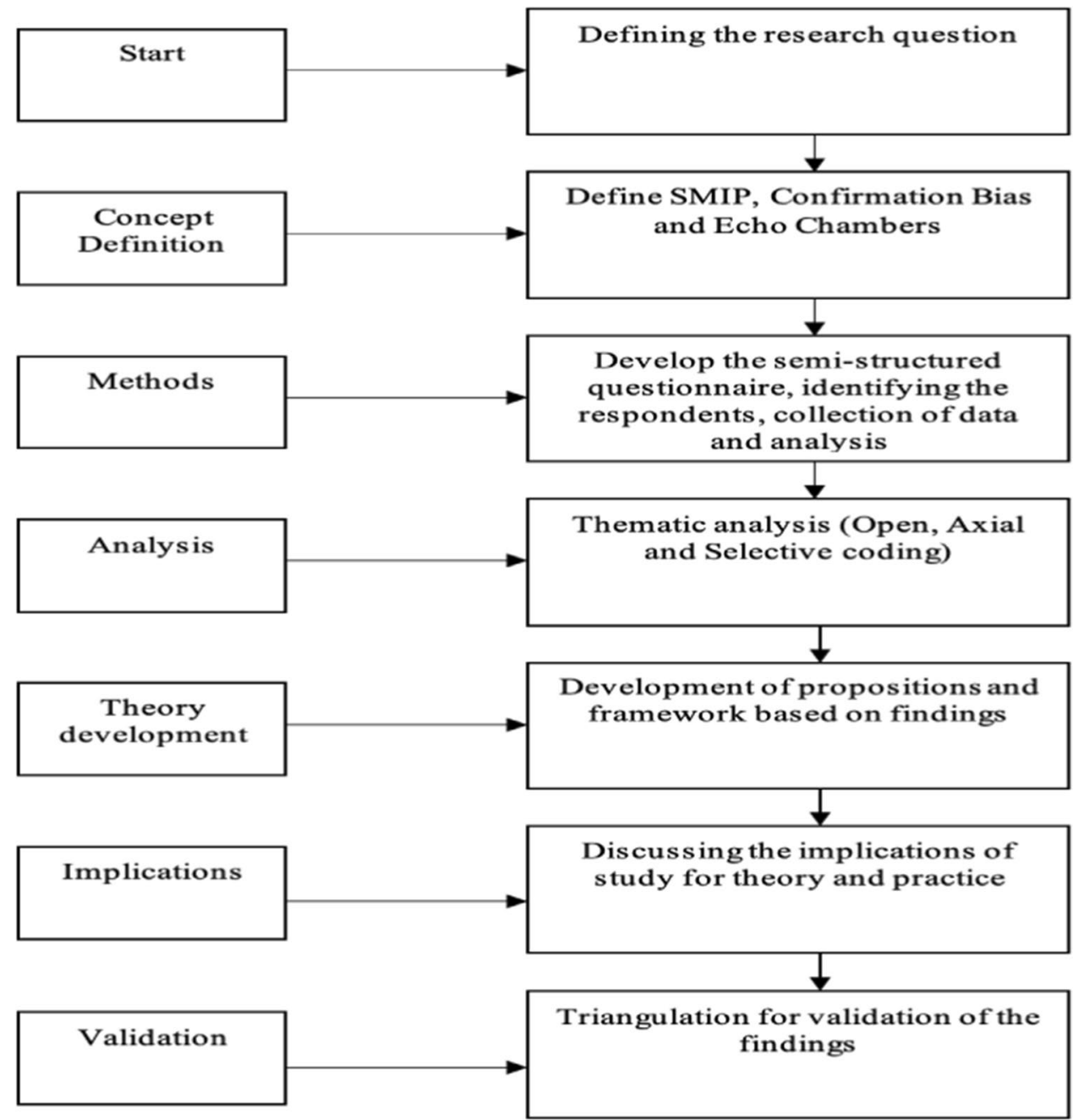

views of participants and it provides a pre-defined coding scheme. We conducted primary, secondary, and tertiary analysis (three-layer analysis i.e., open, axial, and selective coding) since it was capable of consolidating and facilitating the raw data to meaningful themes.

Four key propositions emerged out of the data that was analysed through three stages. The first stage of the data analysis involved reading the transcripts, identifying differences and similarities between responses to the interview questions, and observing emerging themes. This stage is about conceptualisation and description of the data at basic level and is commonly known as open coding. In the second stage, we analysed the relationship among open codes leading to develop the axial codes. Second stage of axial coding of the data analysis involved further categorisation, by matching the open codes to the underlying constructs of confirmation bias. The third stage of data analysis known as selective coding employed for identifying the relationship among axial codes to map the phenomena of emerging echo chambers. Through this three-stage process of data analysis, we shed new light on the role of confirmation bias in participants involved in supply chain information processing. The coding scheme is presented in Appendix Table 8. Table 2 presents the triangulation approach, where we found the convergence through industry reports, research articles and data collected from the participants.

\section{Key Findings \& Emergent Themes}

This section presents key findings under four themes that emerged from the data, namely, environmental setting, actors, mechanism, and outcome. Each of these themes are discussed in the context of supply chains and form the basis for the proposed framework of SMIP and the emergence of echo chambers.

\subsection{Environmental Setting}

The surroundings and fragmented society derive the unequal status and economic displacements in every part of the world (Bessi, 2016). The society represents individuals 
Table 1 Interviewee profile

\begin{tabular}{|c|c|c|c|c|}
\hline No. & Code & Job title & Nature of work & $\begin{array}{l}\text { Years of } \\
\text { Experi- } \\
\text { ence }\end{array}$ \\
\hline 1 & $\mathrm{R} 1$ & Senior Manager & Sales \& Marketing & $>10$ \\
\hline 2 & $\mathrm{R} 2$ & Senior Manager & Logistics \& Supply Chain & $>10$ \\
\hline 3 & R3 & Marketing Executive & Sales \& Marketing & $6-10$ \\
\hline 4 & $\mathrm{R} 4$ & Logistics Manager & Sales \& Marketing & $6-10$ \\
\hline 5 & R5 & Corporate Finance Executive & Logistics \& Supply Chain & $1-5$ \\
\hline 6 & R6 & Logistics Manager & Logistics \& Supply Chain & $1-5$ \\
\hline 7 & R7 & Corporate Finance Executive & Sales \& Marketing & $1-5$ \\
\hline 8 & $\mathrm{R} 8$ & Engineer & Consulting & $1-5$ \\
\hline 9 & R9 & Corporate Finance Executive & Consulting & $1-5$ \\
\hline 10 & $\mathrm{R} 10$ & Engineer & Logistics \& Supply Chain & $1-5$ \\
\hline 11 & $\mathrm{R} 11$ & Corporate Finance Executive & Manufacturing & $1-5$ \\
\hline 12 & $\mathrm{R} 12$ & Senior Manager & Sales \& Marketing & $6-10$ \\
\hline 13 & $\mathrm{R} 13$ & Logistics Manager & Logistics \& Supply Chain & $1-5$ \\
\hline 14 & $\mathrm{R} 14$ & Sales/ Marketing Executive & Logistics \&Supply Chain & $1-5$ \\
\hline 15 & $\mathrm{R} 15$ & Engineer & IT Services/ Software & $6-10$ \\
\hline 16 & $\mathrm{R} 16$ & Senior Manager & Logistics \& Supply Chain & $5-10$ \\
\hline 17 & $\mathrm{R} 17$ & Senior Manager & Logistics \& Supply Chain & $>10$ \\
\hline 18 & $\mathrm{R} 18$ & Logistics Manager & Logistics \& Supply Chain & $1-5$ \\
\hline 19 & $\mathrm{R} 19$ & Senior Manager & Logistics \& Supply Chain & $1-5$ \\
\hline 20 & $\mathrm{R} 20$ & Consultant & Consulting & $1-5$ \\
\hline 21 & $\mathrm{R} 21$ & Engineer & Logistics \& Supply Chain & $1-5$ \\
\hline 22 & $\mathrm{R} 22$ & Corporate Finance Executive & Consulting & $1-5$ \\
\hline 23 & $\mathrm{R} 23$ & Senior Manager & Manufacturing & $6-10$ \\
\hline 24 & $\mathrm{R} 24$ & Senior Manager & Manufacturing & $6-10$ \\
\hline 25 & $\mathrm{R} 25$ & Engineer & IT Services/ Software & $1-5$ \\
\hline 26 & $\mathrm{R} 26$ & Senior Manager & IT Services/ Software & $1-5$ \\
\hline 27 & $\mathrm{R} 27$ & Logistics Manager & Construction/ Real Estate & $6-10$ \\
\hline 28 & $\mathrm{R} 28$ & Marketing Executive & Food \& Beverage & $5-10$ \\
\hline 29 & R29 & Senior Manager & Financial Services & $>10$ \\
\hline 30 & $\mathrm{R} 30$ & Logistics Manager & Logistics \& Supply Chain & $1-5$ \\
\hline 31 & $\mathrm{R} 31$ & Logistics Manager & Logistics \& Supply Chain & $6-10$ \\
\hline 32 & $\mathrm{R} 32$ & Engineer & IT Services/ Software & $1-5$ \\
\hline 33 & $\mathrm{R} 33$ & Engineer & Manufacturing & $1-5$ \\
\hline 34 & $\mathrm{R} 34$ & Director/ Founder & Food \& Beverage & $>10$ \\
\hline 35 & R35 & Director/ Founder & Logistics \& Supply Chain & $>10$ \\
\hline
\end{tabular}

with democratic and republican mind set from political discourse view. Democrats and republicans develop a ground for opposite views with their own belief system and philosophy (Neiman et al., 2016). The role models, influencers and benchmarks advance the environmental setting. Additionally, the persuasion of social and human ideas, social security, government policies and economic principles lay the foundation in the interaction of diverse stakeholders on different platforms influencing the surrounding factors (Barnett, 2007). These adjoining factors further rise to the diverse culture that has a close relationship towards the active participation and supporting the diverse activities in a supply chain. Table 3 displays the related quotes and codes to environmental setting that represents the formation of echo chambers.

\subsection{Actors}

Social media generates large volume of data that is influenced by agents or actors. These agents (e.g., partisan, and bipartisan) work around the specific features and characteristics that focus on certain pain points ranging from individuals to large entities such as supply chain (Shin \& Thorson, 2017). For instance, Facebook uses the private data of users 


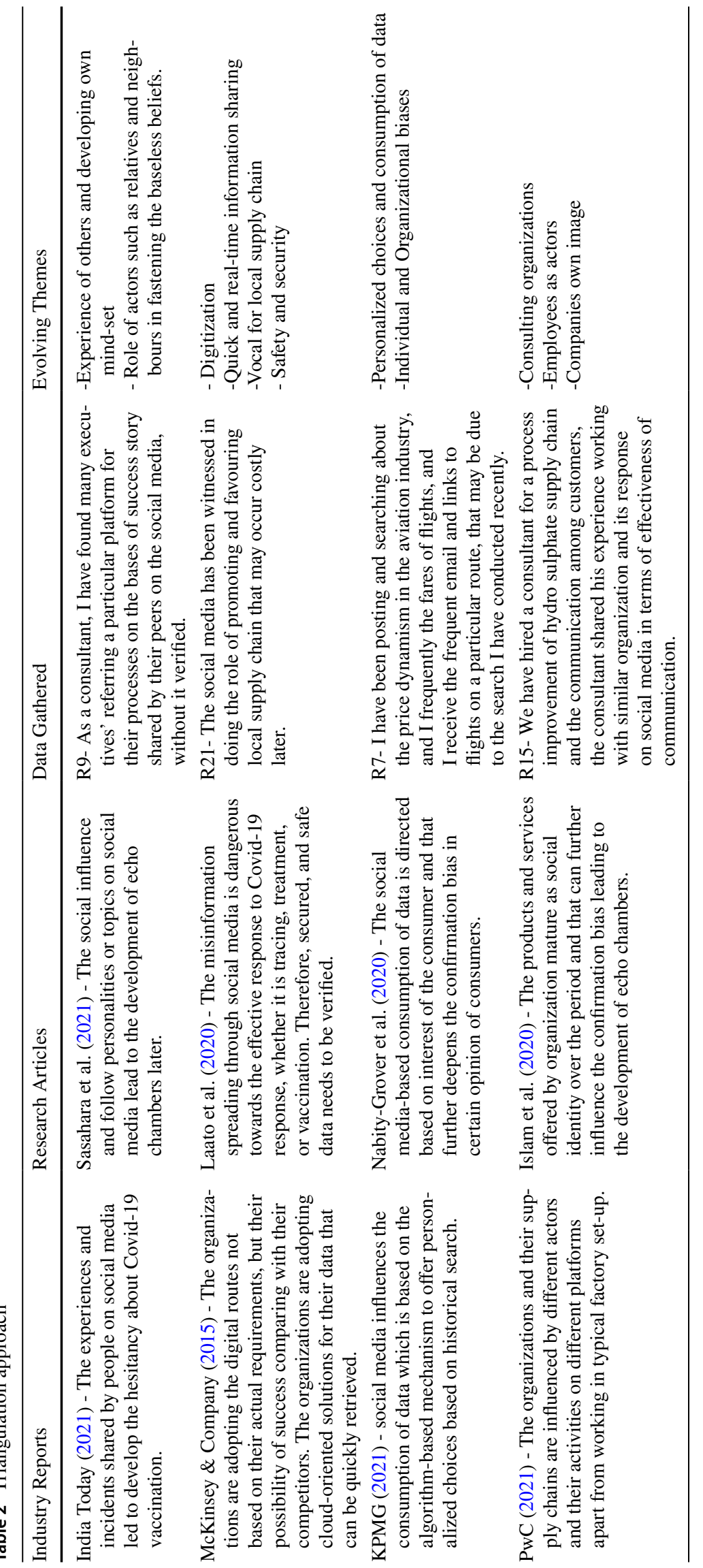


to expose them with large amount of content (Bessi, 2016). The companies or product specific characteristics distract the users from the fundamentals through social media and it serves as a society-fracturing tool. The consulting firm's belief as an actor strengthens when their success or failure stories are witnessed over social media (Anand et al., 2007). The belief system further gets a strong bond when other similar entities succeed or fail that lead to make their belief system more extreme (Teo et al., 2008). Supply chain interaction with social media lead information exposes it to numerous topics and global events. For example, Covid19 directed practitioners to take certain actions to derive the business operations that define the social identity of the supply chain, which plays a critical and influential role in supply chain decisions. Table 4 displays the related quotes and codes for actors that contribute to the formation of echo chambers.

\subsection{Mechanism}

In the age of social media not only in individual, but also in business to individual and business to business interactions, the personalisation is pervasive (Neves et al., 2014). The personalisation facilitates the higher user efficiency and greater revenue to the platform by providing relevant content to the user needs. Feeds, group membership, product recommendation and e-advertisement pervade the system towards personalization (Tim et al., 2018). Data and content selection algorithm consider the user's characteristics, activities on social media and interests based on past behaviour to display the personalised list of content (Stepan et al., 2016). The personalized content and news feed along with other sources can lead to filter bubble in developing a tunnel vision for individuals to groups (Pariser, 2011). This way practitioners as well as systems like supply chain develop their ideological bubble. On the other hand, the choices that individuals make on social platform facilitate group and systemic biases to polarise the belief system (Dubois \& Blank, 2018). Content is categorised into diverse groups based on sensitive attributes viz. some stories may have a particular political orientation (liberal or conservative) or a topic that can impact a particular sector of the business or supply chain.

The objective of data selection algorithm is to match the user needs to maximise the positive feedback; hence it must learn and organise about the topics that the user is most interested in. Table 5 displays the related quotes and codes for mechanism that represents the formation of echo chambers.

\subsection{Outcome}

The digital economy and environment have steered the multitudes of information platforms (Tim et al., 2021). The 


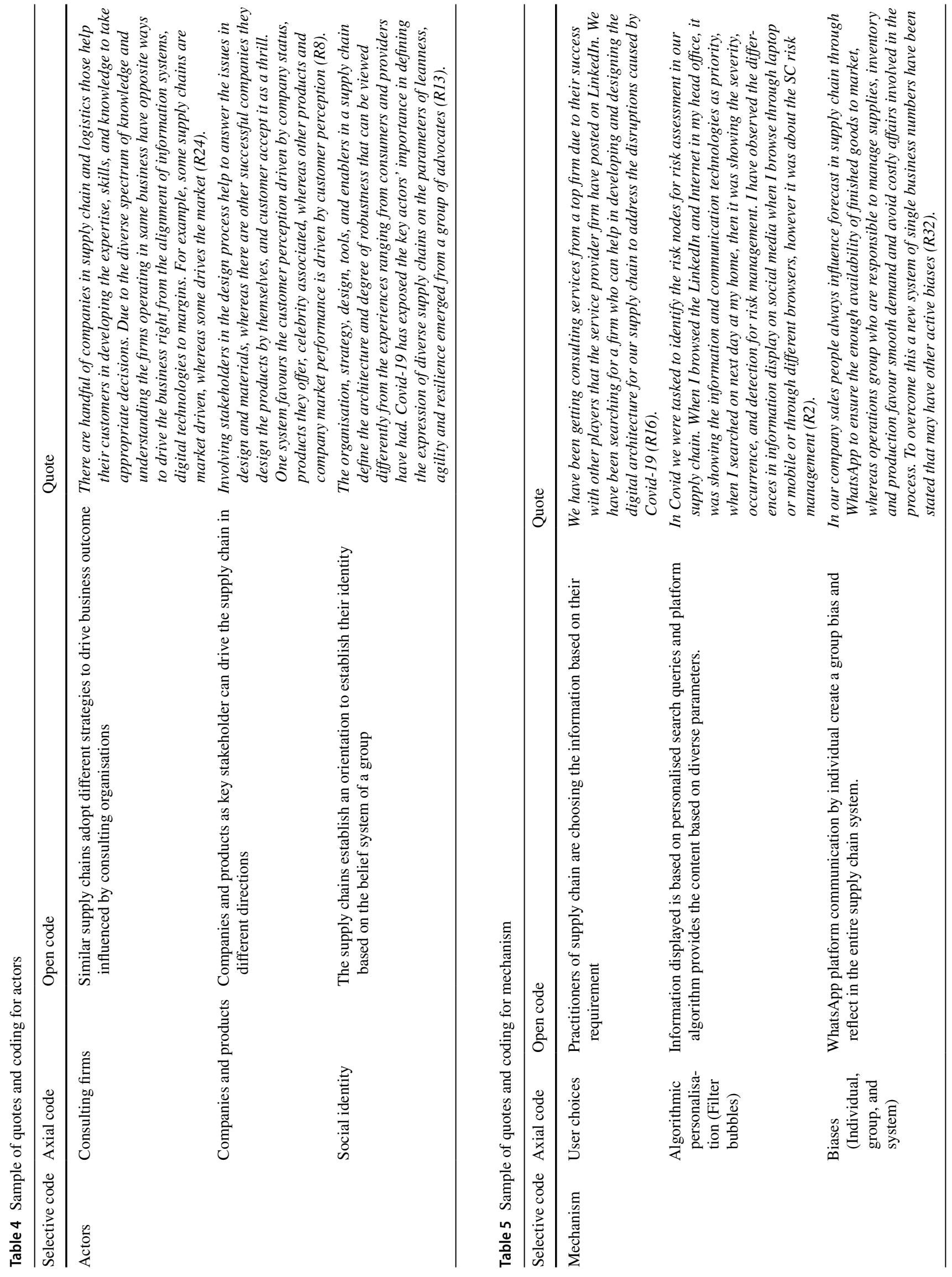


practicing managers in supply chains should examine and analyse large amount of information and by doing so they may favour or develop certain channel of information in their day-to-day operations. This selection of information channels creates the risk of online echo chambers that reinforces the pre-existing biases and beliefs (Flaxman et al., 2016). The choice of social media platforms or information channels have a significant impact on consumer choice and therefore, exposes risk to stakeholders of supply chain. The familiarity and inclination with a social media source of information outplays as compared to its inherent reliability and trustworthiness (Dwivedi et al., 2018; Butler \& Gray, 2006). This is observed by the fact that even though witnessing an increase in computerisation and availability of information around $33 \%$ of the companies have not analysed their supply chains for the potential sources of disruption (Gomber et al., 2018). The remaining $67 \%$ of the companies have developed their echo-chambers based on the success and failure stories pre and during Covid-19 to ensure the continuity of their business. Covid-19 has compromised many individual accounts on social as well as personal space that indirectly influence the supply chains and hence consider investing in strengthening cyber security, increasing flexibility, strengthening local supply chains and identify the risk nodes for better response during emergency situations (Spanaki et al., 2019). Table 6 displays the related quotes and codes to outcome that represents the formation of echo chambers.

Following the thematic analysis, the study captured different open codes from the data of interview. After multiple iterations, back and forth, we recognized the axial codes those were further integrated to develop selective codes. In summary, our study identifies four selective codes presented in Table 7.

\section{Propositions and Framework for SMIP in Supply Chains}

In this section, we developed four propositions based on the thematic analysis of the data. The propositions demonstrate the contextual complexity of supply chain information sharing and the impact of information sharing that is highly nuanced.

Proposition 1: The off-line and online experiences of diverse stakeholders and degree of exposure to social media set the diverse expectations from a supply chain and influence the partisan and bi-partisans orientation.

The offline experience of individuals, professionals and organisations acts as base to model their cognitive behaviour in online platforms and social media (Arnott, 2006). Users expect the content in line of their expectation and experience on internet and that further influence their beliefs. In the words of R30 (Logistics coordinator with 3 years of experience from logistics and supply chain), "Earlier it was expected that internet and other social media can provide greater transparency by offering more content, however with varied expectations and experiences of stakeholders has developed a different kind of environment for users and their thought process". Many social media users consume the information without seeing the source and develop their theories for the topic of their interest or related to it (Westerwick et al., 2017; Zamani \& Pouloudi, 2021). Social media is a mix of genuine and fake content posted by related individuals, groups or organisations and it is very difficult to make out and filter the true ones (Tim et al., 2018). In the words of R9 (Analyst with 3 years of experience from consulting), "Many of the supply chain decisions are aligned with the incidents reported on social media to save the image of an organisation. Additionally, many consumers on the experience of their friends or relatives opt social media to complain or connect to company in case of product failure and this has been very frequent during Covid-19 due to face-to-face restrictions. In some cases, the influential people amplify the voice of actual complainer". This way the exposure and expectation from social media platforms including online and offline experiences act as a basis to develop a certain belief system and influence the activities of value chain.

Proposition 2: Supply chain consulting firms create and develop new forms of knowledge and information that help in displaying the social identity. The products and service behaviour are tracked to recognise the consumer choices for personalised content to be offered.

In the age of information many functions of a business are using social media to understand the market trends and reaction to a specific offer (Felix et al., 2017). It has become more obvious for supply chain and related professionals, since facilitating the consumer is one of the key objectives and most of the consumers are present and use social media for many decisions that further influence the activities of a supply chain (Fu et al., 2013). In the words of R26 (Logistics manager with 10 years of experience from construction), "The performance of a supply chain is measured, how the product and organisational efforts are recognized and perceived by real consumers, therefore to track the product performance and resolve the complaints we are connected to our consumers through social platforms such as Twitter, Facebook and LinkedIn and also we consider consulting firms advices and piece of information shared on their websites regarding changing needs of a supply chain". The expectations of customers are also advanced by some of the consulting firms indirectly and therefore the organisations map their social identity to match the customer expectation and the cluster they belong to (Sharif, 2002). In the words of R31 (Logistics 


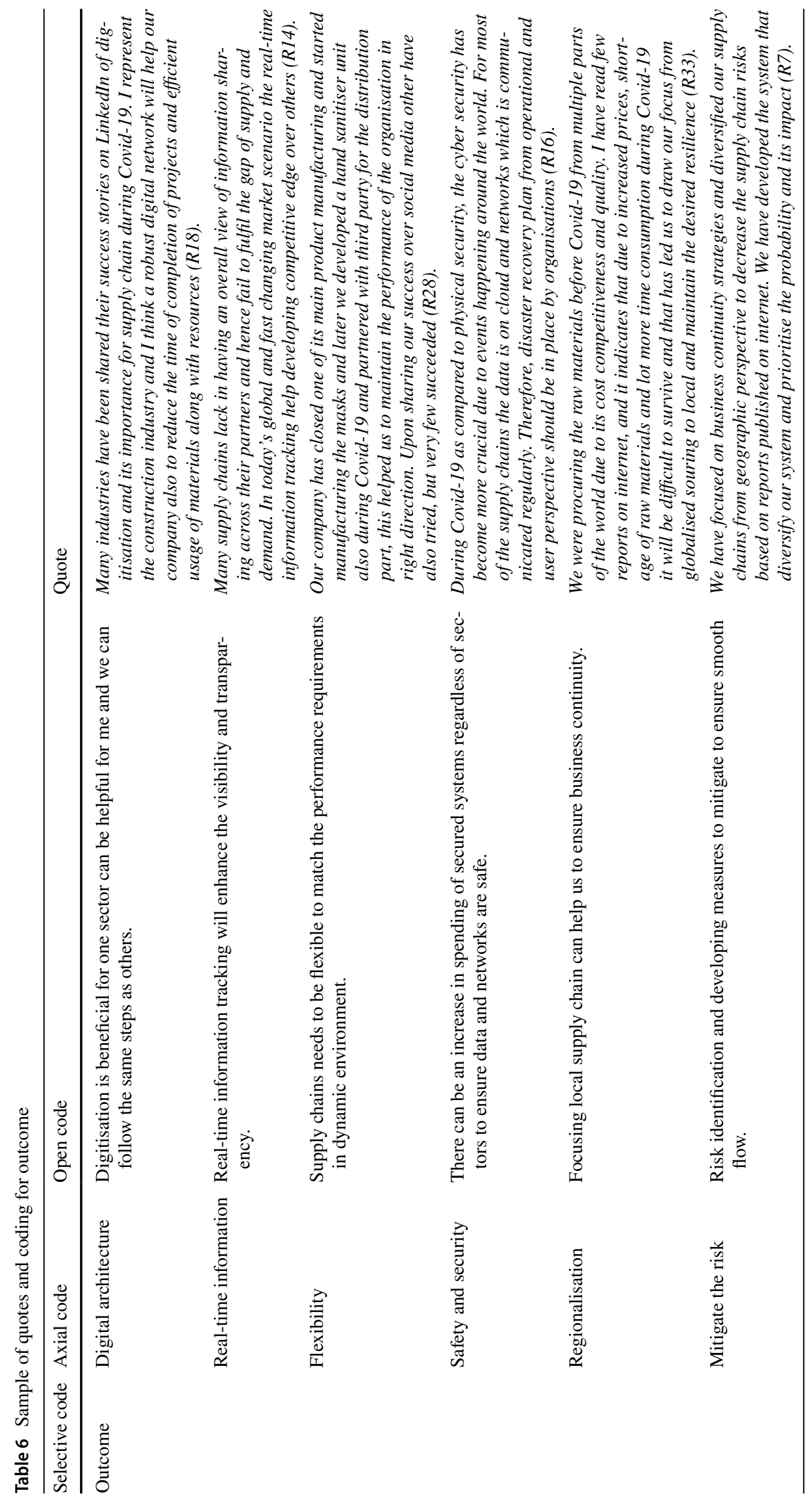


Table 7 Summary of findings

\begin{tabular}{|c|c|c|}
\hline Selective Code & Axial Code & Meaning of different Open Codes \\
\hline Environmental setting & $\begin{array}{l}\text { Expectation } \\
\text { Experience } \\
\text { Information platforms }\end{array}$ & $\begin{array}{l}\text { Social media influence the expectations of varied consumers based on experiences they have } \\
\text { in physical, online, and internet-based platforms. }\end{array}$ \\
\hline Actors & $\begin{array}{l}\text { Consulting Firms } \\
\text { Companies and products } \\
\text { Social Identity }\end{array}$ & $\begin{array}{l}\text { Different consulting organizations offer different solutions to the concerns of customer } \\
\text { engagement to improving their supply chains, that further influence the positioning of com- } \\
\text { panies and products in the form the celebrity endorsement and market performance. The } \\
\text { social identity of a product/organization is perceived based on experiences they have. }\end{array}$ \\
\hline Mechanism & $\begin{array}{l}\text { User Choices } \\
\text { Filter bubbles } \\
\text { Biases }\end{array}$ & $\begin{array}{l}\text { The executives of upstream and downstream access the social media information based on } \\
\text { their requirement and that is further advanced based on algorithmic personalization when } \\
\text { it comes to ultimate consumer and leads to filter bubbles. The specific groups on different } \\
\text { platforms may create certain biases or myopic view to certain processes in the topics of } \\
\text { their interest. }\end{array}$ \\
\hline Outcome & $\begin{array}{l}\text { Digital architecture } \\
\text { Real-time information } \\
\text { Flexibility } \\
\text { Safety and security } \\
\text { Regionalization } \\
\text { Mitigate the Risk }\end{array}$ & $\begin{array}{l}\text { Success of a digital architecture for one business may be helpful for my business based on } \\
\text { LinkedIn sharing. The flexible layout of the company is directly related to the capability of } \\
\text { a company and not the copy pasting ensure the success of business activities. Many organi- } \\
\text { zations are concerned about the safety and security of data along with regionalization of } \\
\text { their supply chain activities to mitigate the risk, due to several stories shared on social } \\
\text { media by practitioners and consulting organizations, which may not be the case. }\end{array}$ \\
\hline
\end{tabular}

manager with 10 years of experience from logistics and supply chain), "The supply chains design their networks to avoid the role conflict and maintain intergroup relations due to the large players involved in delivering a product and offering aftersales services, therefore the supply chain develops a specific social identity to create the user perception". The network structure and architecture can act as an actor to influence the user choices on social media. These actors exchange and develop their knowledge based on their feeds.

Proposition 3: User choices trigger the algorithmic personalisation that form the filter bubbles and vice-versa. These filter bubbles influence the individual, group, and system biases and vice-versa and it creates the echochambers along the supply chain.

The opinion and existing knowledge gained through websites, blogs and other forms of internet help forming the choices of the content a consumer want to view (Zhao et al., 2020). This represents the polarisation cycle from the view of confirmation bias that is pervasive. In the words of R35 (Director with more than 10 years of experience from logistics and supply chain), "We use multiple personalisation approached on the basis of user clusters and their search history to enhance the loyalty of the user to our portal that further advanced the product recommendation through genetic adaptive architecture for profiling”. This personalisation creates the filter bubble for individuals and groups (Garrett, 2009; Kapoor et al., 2018). In the words of R20 (Consultant with 3 years of experience from consulting), "In one of the experiences with my client, I offered applications from different vendors for enterprise resource planning, to my surprise and save on time, they advised me to describe the product offered by Oracle. Two years later, when I visited another organisation from the region, they quoted the earlier organisation success and opted for Oracle". Therefore, the polarisation occurs due to the individual, group, and system biases.

Proposition 4: The user's choices, experiences and algorithmic personalisation influence the confirmation bias that further develop the echo chambers in supply chains. As a result, some supply chains are focusing more on digitalisation or monitoring real-time information, where some others are investing heavily on cyber security, risk mitigation and regionalisation.

Due to the exposure to large amount of data in supply chain processes, tracking and monitoring of customers and their pain points through social media becomes a complex task (Manavalan \& Jayakrishna, 2019). There has been huge wave of data and that has been advanced during Covid-19 due to more time spent by public on internet and social media platforms as well as companies interacting with their customers (Nabity-Grover et al., 2020). In the words of R10 (Engineer with 3 years of experience in logistics and supply chain), "The non-face to face interaction to ensure business continuity has turned many organisations to automation and to strengthen their digital architecture, whereas the players those could have avoided this investment on digitisation have also invested and some of them resulted into low return of investment, thus creating an echo chamber with respect to digitisation". 
Supply chains have been found referring to the websites and reports of consulting companies and sharing few success stories have focused on enhancing the flexibility and approaches for identifying and mitigating the risk at different nodes (Anand et al., 2007). With the digitisation, there are more transactions online, therefore online tracking of real-time information is critical. In the words of R25 (Engineer with 5 years of experience in IT services), "With the increase of digital payments and online tracking the security and safety of the systems is critical and have been advised by a consulting firm to spend a specific amount of the revenue in ensuring the networks are secure and we are proceeding in that direction". Separately from this, the focus on local supply chains have been emphasised and realised due to time, safety, and cost of sourcing from global supply chains.

Building on the emergent themes and propositions, a conceptual framework of SMIP and the emergence of echo chambers is presented in Fig. 3.

\section{Discussion}

Research has recently addressed the implications of SMIP in the context of supply chains highlighting issues in decision making (Sharma et al., 2020), risk management (Fu et al., 2013; O'Leary, 2011), sentiment (Wuebben, 2016; Zadeh \& Sharda, 2014). To date however, limited research exists on understanding how manifestations of confirmation bias contribute to the development of 'echo chambers' in the context of supply chains. A context where it has been acknowledged that participants are highly vulnerable to developing echo chambers through confirmation bias (cf. Boutyline \& Willer, 2017; Orji et al., 2020).

Drawing on contemporary literature, we frame the theoretical and empirical contributions of this study ( 2014; Corley \& Gioia, 2011; Zamani et al., 2020). This is attained in several ways. The most salient theoretical contribution of this study is to use the confirmation bias and echo chambers as a lens to study SMIP in the context of supply chain during the Covid-19 pandemic. This is an important contribution as studies linking confirmation bias and echo chambers to supply chains remain under studied (Fu et al., 2013; O'Leary, 2011; Orji et al., 2020). This study also contributes to addressing the grand challenges of IS research (Becker et al., 2015; Winter \& Butler, 2011), by specifically focusing on important socio-technical challenges such as effective IS for emergency management, and leveraging knowledge from data, with the related management of high data volumes (Becker et al., 2015). As this study builds on extant SMIP literature, it makes an empirical contribution by extending the generalisability of SMIP to provide novel insights that have not been reported in previous studies. This is achieved by identifying four themes (e.g., environmental setting, actors, mechanism, and outcome) and developing a set of propositions in the context of supply chains that may affect the extent to which confirmation bias facilitates creation of echo chamber in supply chains.

\subsection{Implications for Research}

This research builds on the cumulative body of knowledge related to SMIP, by rigorously identifying four themes (i.e., environmental setting, actors, mechanism, and outcome) and

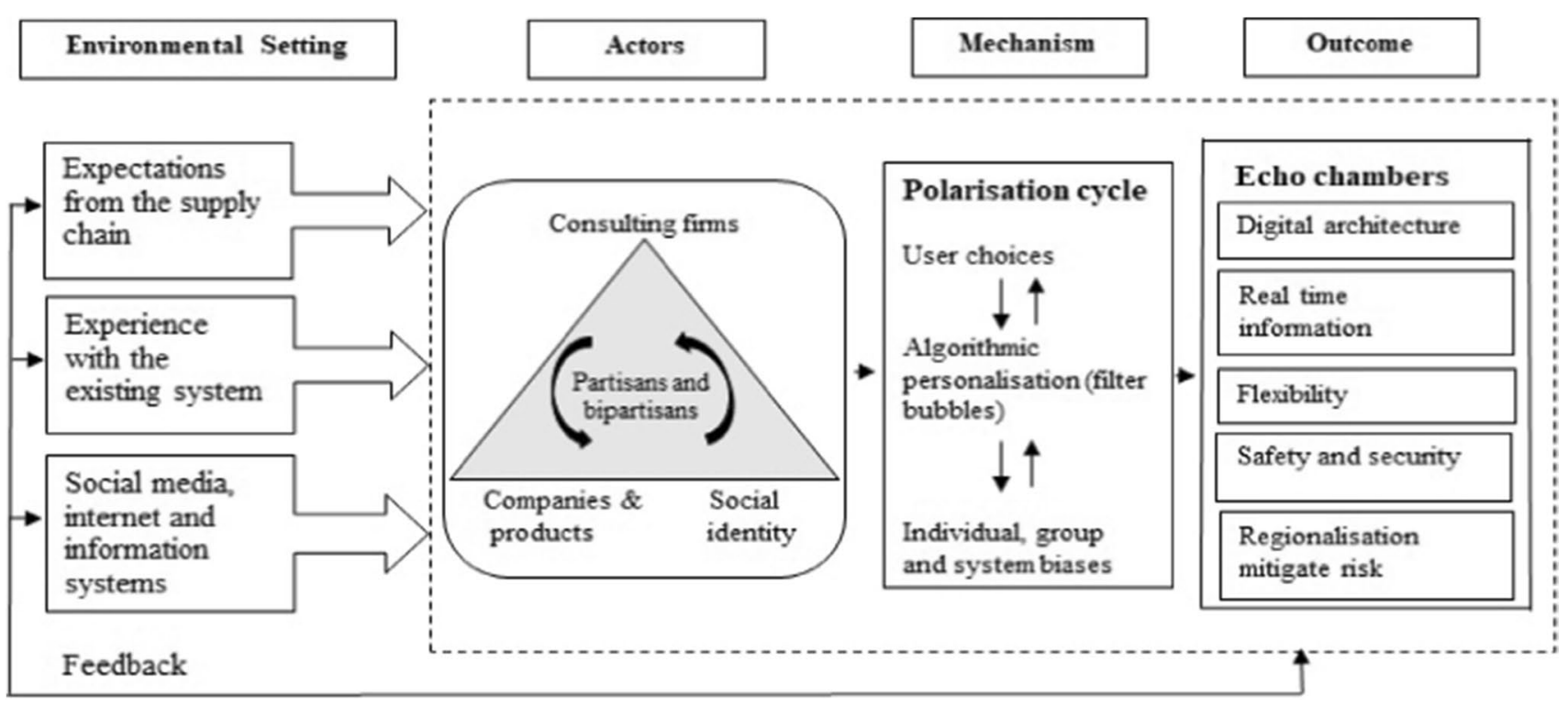

Fig. 3 Proposed framework for social media induced polarisation in supply chains 
developing a set of propositions that provide rich qualitative insights. These propositions, which were developed through the lens of confirmation bias, can enable researchers from a range of disciplines to assess them through hypothesis testing. The proposed framework conceptualises the complex phenomenon of SMIP, which in turn provides a structure for researchers to examine the four themes collectively or individually, and in different contexts. This study extends previous studies by demonstrating that there is a reciprocal, reinforcing relationship between confirmation bias and echo chambers that accelerates SMIP, as opposed to just the social media platform itself. Our study displays the tendency to search, recall and favour the information with reference to existing beliefs and experiences that professionals have online and offline. Further, our study contributes to SMIP literature by presenting the relationship among different aspects developed based on filter bubbles created and user choices leading to polarized in supply chains. Other studies in the literature indicate the other forms and ways of forming confirmation bias that leads to emergence of echo chambers. For instance, Sasahara et al. (2021) pointed out that minimum social media exposure also influences the thought process and developing a network of choice by un-following people of a different mind-set, leading to homogenous communities and echo chambers. Apart from developing polarization and echo chambers, confirmation bias reveals the personal traits of the individual, group, and system specifically in dynamic times such as Covid-19. Our study has unveiled the structure of elements that lead to the creation of echo chambers across the supply chain.

\subsection{Implications for Practice}

The research provides further evidence to support supply chain practitioners and members of online communities to reflect and reassess their pre-existing biases (Parra et al., 2021) and how their choice of social medial platforms can positively or negatively reinforce this deep-seated belief system. Before adopting, referring, and developing an opinion about the information on social media that can directly or indirectly influence the supply chain, it is imperative to analyse and understand (i) the source of information (ii) validation of information, and (iii) openness while considering the information. Managers need to increase awareness about highly influential nature of online and offline information in terms of employees' acceptance of information received via social media and their role as consumer and producer of this information further. Managers need to understand the highly complex, contextualised environment of supply chains due to the large number of actors involved in the ecosystem, perception, orientation of the organisation, type of products and what kind of social identity their supply chain is displaying to online consumers. The managers can identify the nodes of filter bubbles and clusters of echo chambers in their supply networks by employing the proposed framework to solve the issues occurring in their day-to-day operations. The practicing managers, governments and consumers of the information can work together to solve the problems of fake information and developing the perspective on that basis. The technology and social media companies can come together in developing technologies those can identify the fake information and reduce the incentives for the beneficiaries of misinformation on different platforms. The lack of appropriate and precise information can further create information vacuum that offer space for misinformation to circulate. Managers should have a strong focus on the scope of developing echo chambers especially when there is limited information about what is not known. Finally, individuals need to be informed about the implications of dispersed information and how it can lead to a 'rose tinted' view of the real-world.

\subsection{Limitations and Future Research}

We acknowledge this study has two limitations, which also offer directions for future research. First, the study was conducted during a global pandemic that behaved like a 'once-in-a-century pathogen' (Gates, 2020) which led to restricted movements due to national lockdowns and heightened emotive discussions around its source and solution. Future research could consider contextual factors such as the role of organisational culture which has not been adequately explored in this context, and there is a need for research linking social media technology to national culture (Gupta et al., 2018; Gupta et al., 2019). Second, the utility of the proposed framework for SMIP in supply chain has not been evaluated. Future studies could adopt a design science approach to assess its utility in the context of supply chains or extend it to other social settings to identify the sources and consequences of echo chambers. Despite these limitations, it provides direction for future multidisciplinary research.

\section{Conclusions}

This study draws on confirmation bias and echo chambers to advance understanding of how manifestations of confirmation bias contribute to the development of echo chambers in supply chain information sharing during the Covid-19 pandemic. The findings demonstrate that there is a reciprocal, reinforcing relationship between confirmation bias and echo chambers that accelerates SMIP, as opposed to just the social media platforms itself. Concluding, this study advances understanding of the architecture of confirmation bias that leads to echo chambers, not just in the context of global pandemics, but also in national and international events that can have devastating effects on societies. 


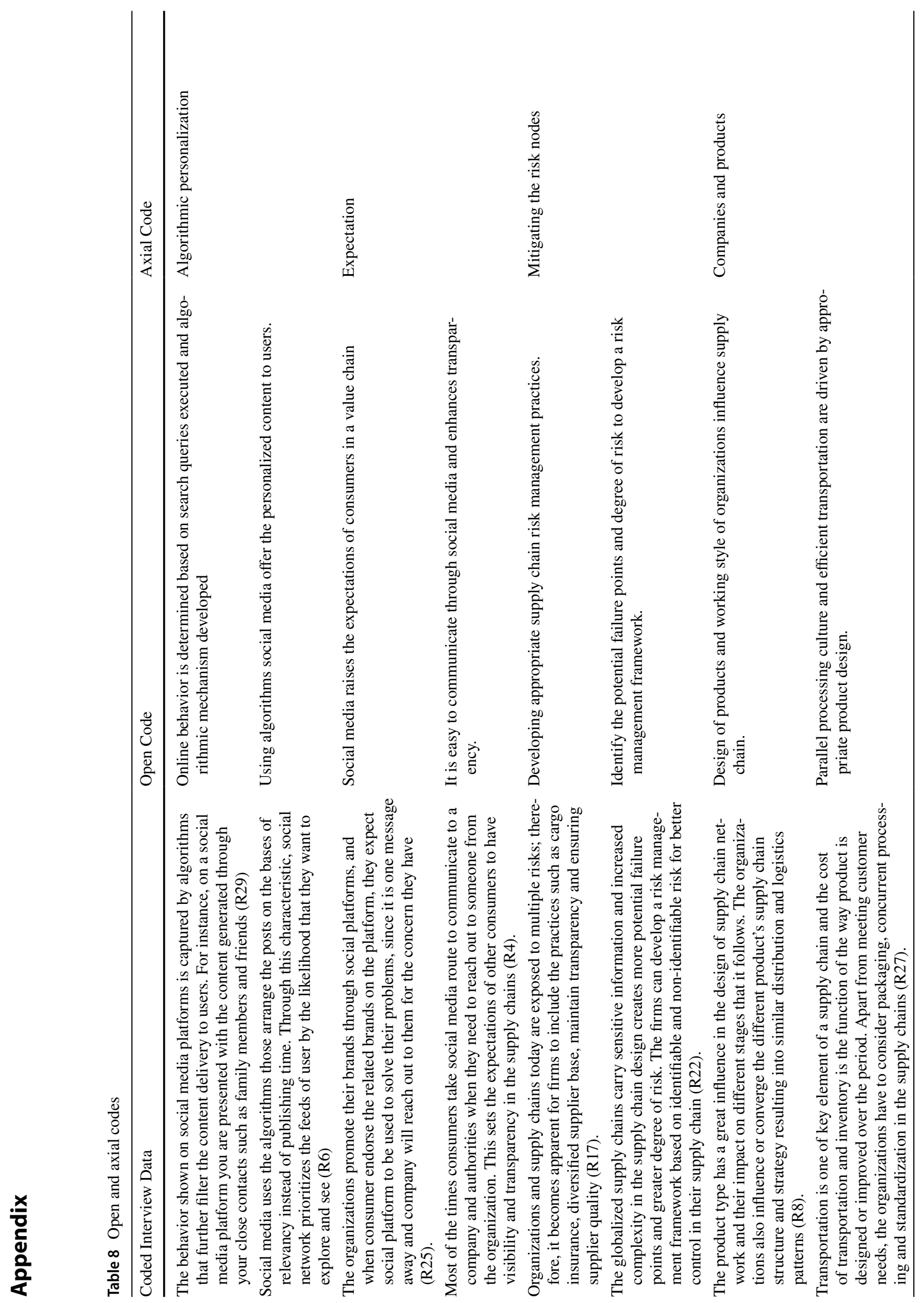




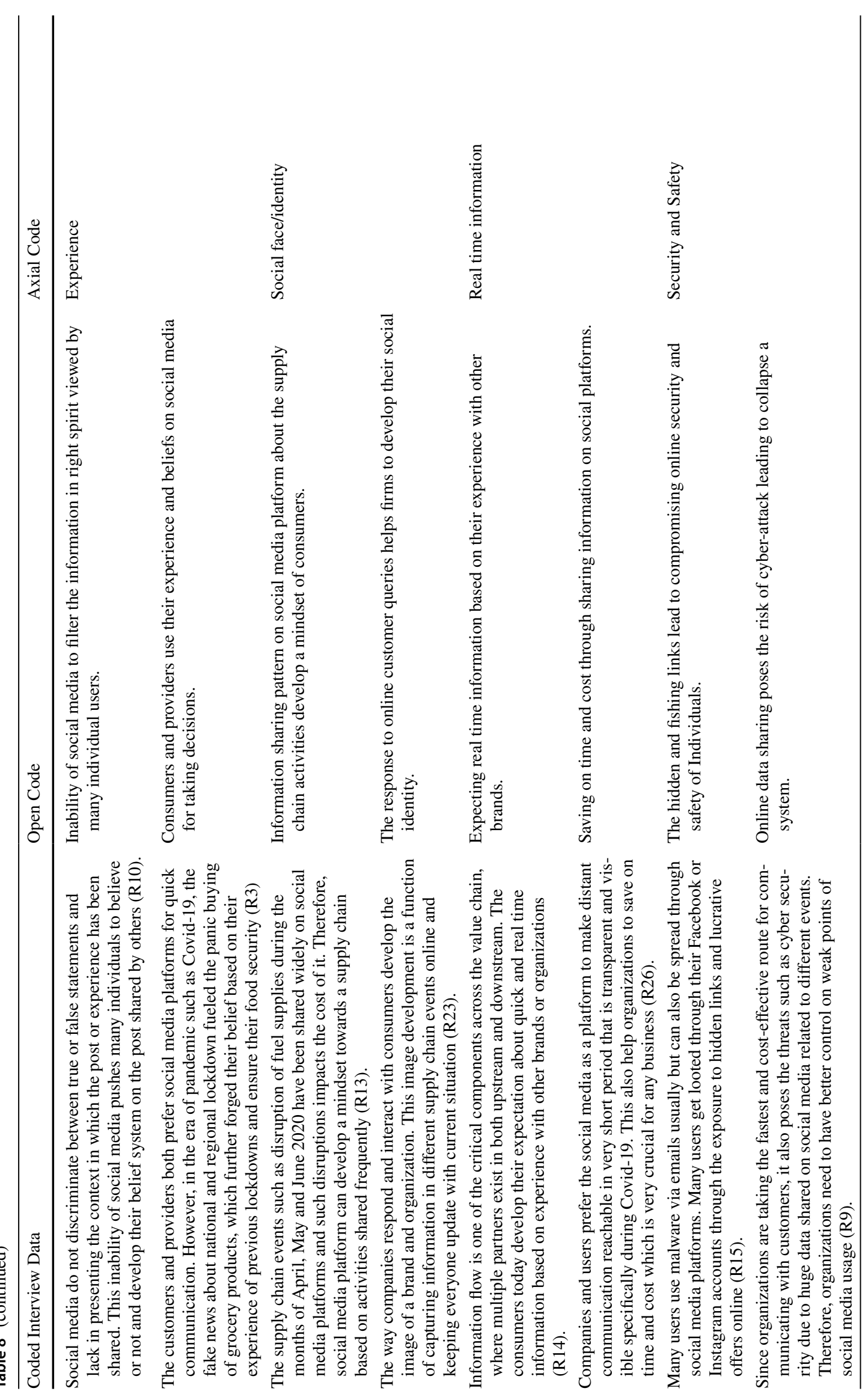




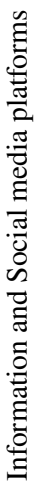

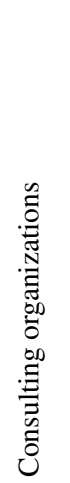

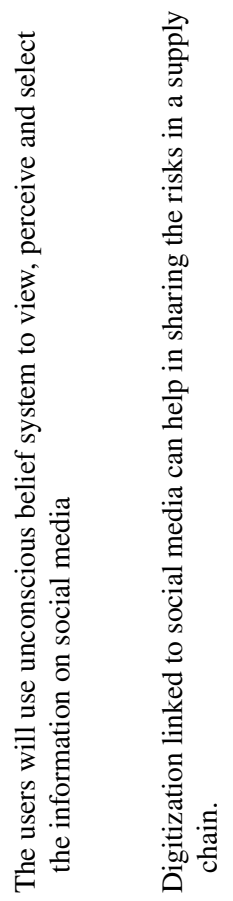

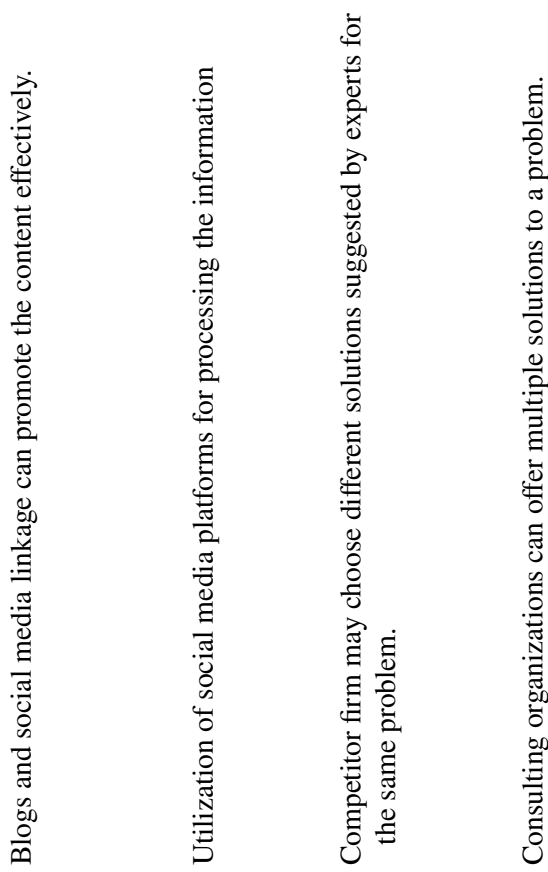

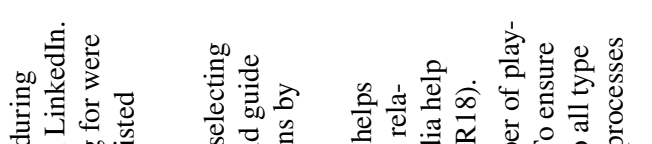

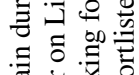

형 홍

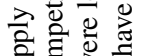

㝕

言言志

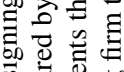

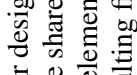

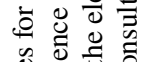

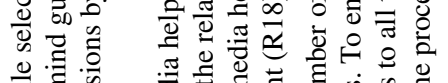

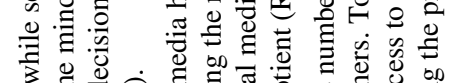

$\stackrel{8}{8}$

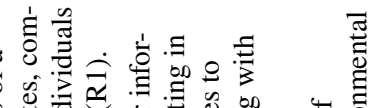

焉

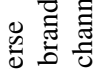

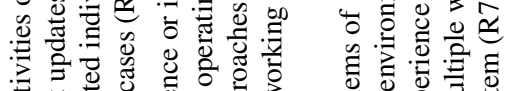

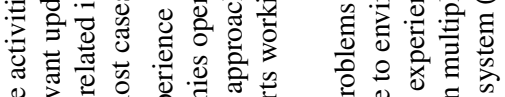

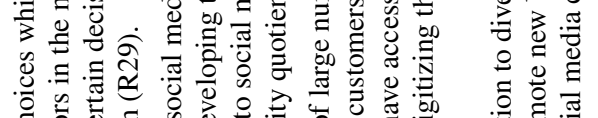

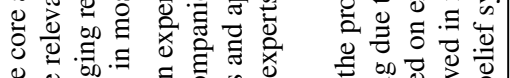

Ð

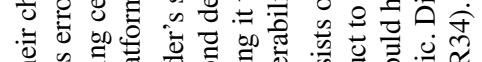

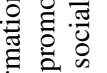

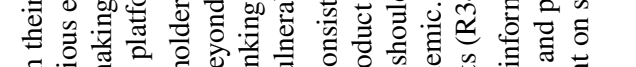

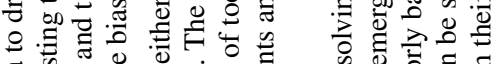

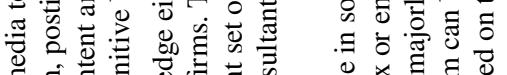

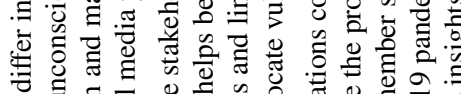

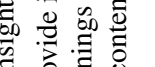

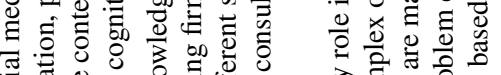

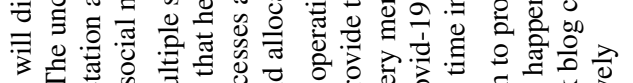

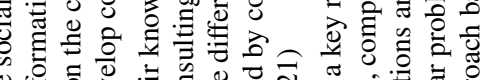

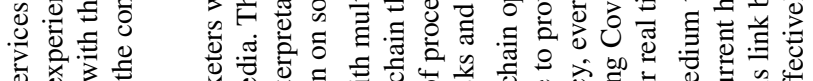

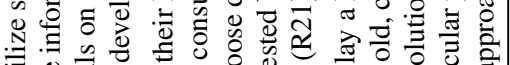

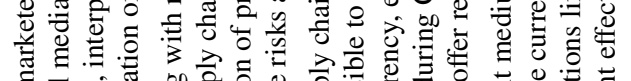

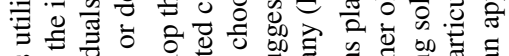

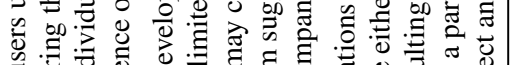

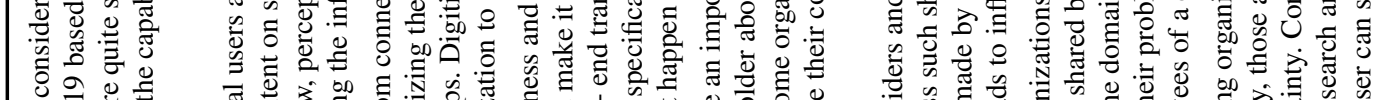

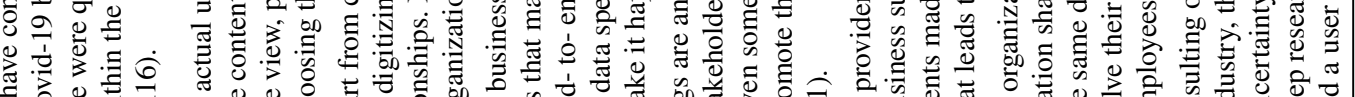

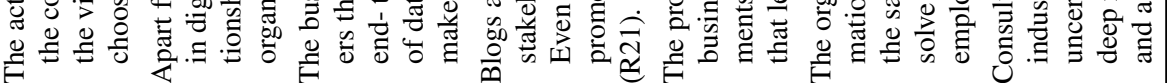




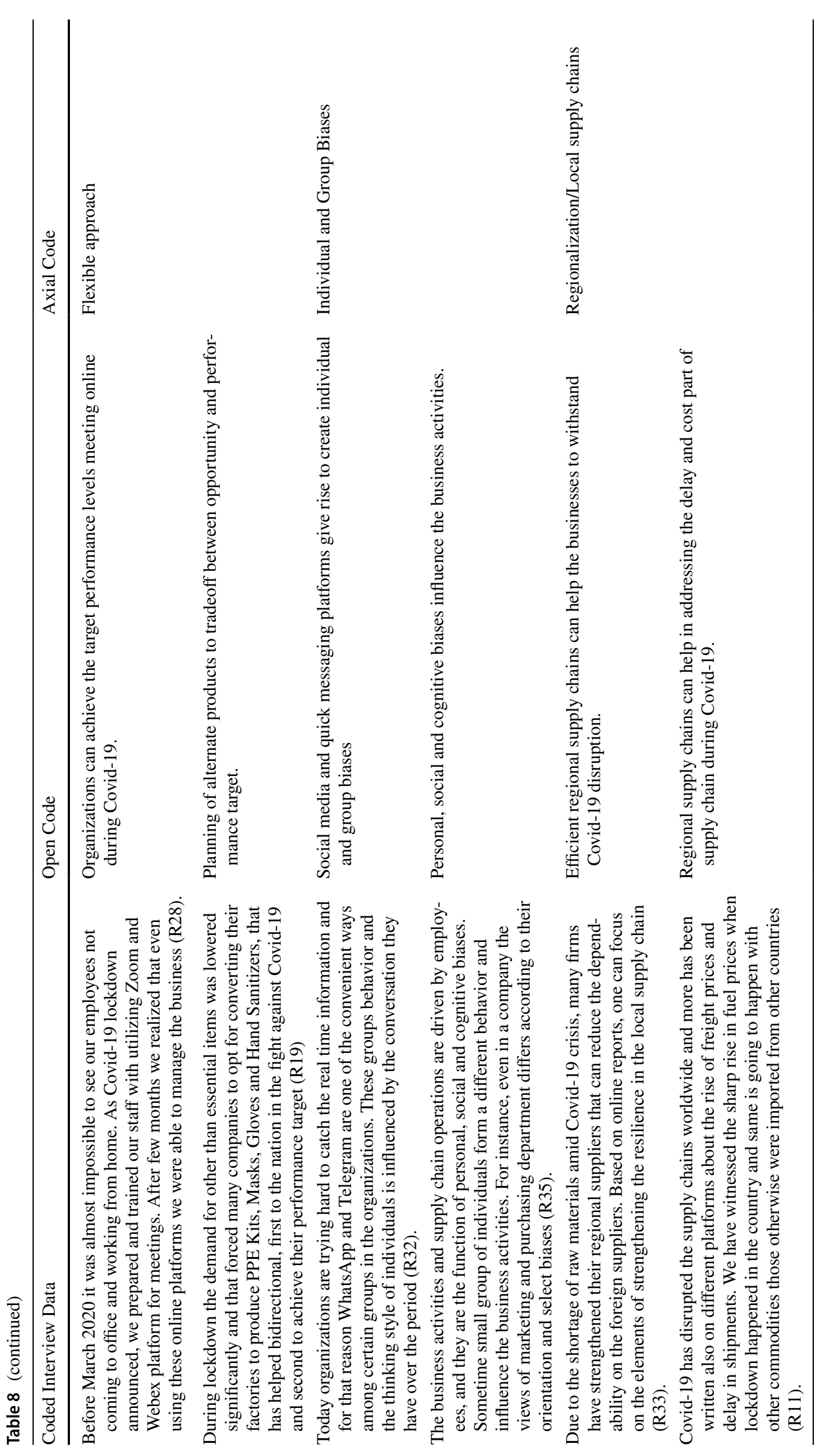




\section{Declarations}

\section{Conflict of interest None.}

Open Access This article is licensed under a Creative Commons Attribution 4.0 International License, which permits use, sharing, adaptation, distribution and reproduction in any medium or format, as long as you give appropriate credit to the original author(s) and the source, provide a link to the Creative Commons licence, and indicate if changes were made. The images or other third party material in this article are included in the article's Creative Commons licence, unless indicated otherwise in a credit line to the material. If material is not included in the article's Creative Commons licence and your intended use is not permitted by statutory regulation or exceeds the permitted use, you will need to obtain permission directly from the copyright holder. To view a copy of this licence, visit http://creativecommons.org/licenses/by/4.0/.

\section{References}

Ågerfalk, P. (2014). Insufficient theoretical contribution: a conclusive rationale for rejection? European Journal of Information System, 23, 593-599. https://doi.org/10.1057/ejis.2014.35.

Anand, N., Gardner, H. K., \& Morris, T. (2007). Knowledge-based innovation: Emergence and embedding of new practice areas in management consulting firms. Academy of Management Journal, $50(2), 406-428$.

Arnott, D. (2006). Cognitive biases and decision support systems development: a design science approach. Information Systems Journal, 16(1), 55-78.

Atlantic Council (2019). Bolivia reflects the deep polarization crisis in Latin America. Available at- https://atlanticcouncil.org/blogs/ new-atlanticist/bolivia-reflects-the-deep-polarization-crisis-inlatin-america. Accessed 1 July 2021

Barberá, P., Jost, J. T., Nagler, J., Tucker, J. A., \& Bonneau, R. (2015). Tweeting from left to right: Is online political communication more than an echo chamber? Psychological Science, 26(10), $1531-1542$

Barnett, M. L. (2007). Stakeholder influence capacity and the variability of financial returns to corporate social responsibility. Academy of Management Review, 32(3), 794-816.

Batrinca, B., \& Treleaven, P. C. (2015). Social media analytics: a survey of techniques, tools and platforms. AI \& Society, 30(1), 89-116.

Becker, J., Vom Brocke, J., Heddier, M., \& Seidel, S. (2015). In search of information systems (grand) challenges. Business \& Information Systems Engineering, 57(6), 377-390.

Benbasat, I., Goldstein, D. K., \& Mead, M. (1987). The case research strategy in studies of information systems. MIS Quarterly, 369-386

Bessi, A. (2016). Personality traits and echo chambers on facebook. Computers in Human Behavior, 65, 319-324.

Bhagwat, R., \& Sharma, M. K. (2007). Performance measurement of supply chain management: A balanced scorecard approach. Computers \& Industrial Engineering, 53(1), 43-62.

Bhardwaj, A., Qureshi, I., Konrad, A. M., \& Lee, S. H. (2016). A two-wave study of self-monitoring personality, social network churn, and in-degree centrality in close friendship and general socializing networks. Group \& Organization Management, 41(4), 526-559.

Birks, D. F., Fernandez, W., Levina, N., \& Nasirin, S. (2013). Grounded theory method in information systems research: its nature, diversity and opportunities. European Journal of Information Systems, 22(1), 1-8.

Boulianne, S., Koc-Michalska, K., \& Bimber, B. (2020). Right-wing populism, social media and echo chambers in Western democracies. New Media \& Society, 22(4), 683-699.

Boutyline, A., \& Willer, R. (2017). The social structure of political echo chambers: Variation in ideological homophily in online networks. Political Psychology, 38(3), 551-569.

Brugnoli, E., Cinelli, M., Quattrociocchi, W., \& Scala, A. (2019). Recursive patterns in online echo chambers. Scientific Reports, 9(1), 1-18.

Brummette, J., DiStaso, M., Vafeiadis, M., \& Messner, M. (2018). Read all about it: The politicization of "fake news" on Twitter. Journalism \& Mass Communication Quarterly, 95(2), 497-517.

Brusset, X., \& Teller, C. (2017). Supply chain capabilities, risks, and resilience. International Journal of Production Economics, 184, $59-68$.

Butler, B. S., \& Gray, P. H. (2006). Reliability, mindfulness, and information systems. MIS Quarterly, 30(2), 211-224. https://doi.org/ $10.2307 / 25148728$.

Carr, C. T., \& Hayes, R. A. (2015). Social media: Defining, developing, and divining. Atlantic Journal of Communication, 23(1), 46-65.

Choi, T. M., Guo, S., \& Luo, S. (2020). When blockchain meets social media: Will the result benefit social media analytics for supply chain operations management? Transportation Research Part E: Logistics and Transportation Review. https://doi.org/10.1016/j. tre.2020.101860

Chou, W. Y. S., Oh, A., \& Klein, W. M. (2018). Addressing healthrelated misinformation on social media. Jama, 320(23), 2417-2418.

Clapham, B., Siering, M., \& Gomber, P. (2019). Popular news are relevant news! how investor attention affects algorithmic decisionmaking and decision support in financial markets. Information Systems Frontiers. https://doi.org/10.1007/s10796-019-09950-w.

Corley, K. G., \& Gioia, D. A. (2011). Building theory about theory building: what constitutes a theoretical contribution? Academy of Management Review, 36(1), 12-32.

Cui, X., Huo, B., Lei, Y., \& Zhou, Q. (2019). The influence of team social media usage on individual knowledge sharing and job performance from a cross-level perspective. International Journal of Operations \& Production Management, 40(5), 1749-1769.

Culnan, M. J., McHugh, P. J., \& Zubillaga, J. I. (2010). How large US companies can use Twitter and other social media to gain business value. MIS Quarterly Executive, 9(4), 243-259.

Culp, S. (2020). A comprehensive approach to managing social media risk and compliance (Retrieved on 10th December, 2020) https:// www.accenture.com/_acnmedia/Accenture/Conversion-Assets/ DotCom/Documents/Global/PDF/Technology_9/AccentureComprehensive-Approach-Managing-Social-Media-Risk-Compl iance.pdf

Del Vicario, M., Scala, A., Caldarelli, G., Stanley, H. E., \& Quattrociocchi, W. (2017). Modeling confirmation bias and polarization. Scientific Reports, 7, 1-9

Dernbecher, S., \& Beck, R. (2017). The concept of mindfulness in information systems research: A multidimensional analysis. European Journal of Information Systems, 26(2), 121-142.

Dezdar, S., \& Sulaiman, A. (2009). Successful enterprise resource planning implementation: taxonomy of critical factors. Industrial Management \& Data Systems, 109(8), 1037-1052.

Dubois, E., \& Blank, G. (2018). The echo chamber is overstated: the moderating effect of political interest and diverse media. Information, Communication \& Society, 21(5), 729-745.

Dwivedi, Y. K., Kelly, G., Janssen, M., Rana, N. P., Slade, E. L., \& Clement, M. (2018). Social Media: The good, the bad, and the ugly. Information Systems Frontiers, 20(3), 419-423. 
Eisenhardt, K. M. (1989). Building theories from case study research. Academy of Management Review, 14(4), 532-550.

Endsley, M. R. (2018). Combating information attacks in the age of the Internet: new challenges for cognitive engineering. Human Factors, 60(8), 1081-1094.

Erkan, I., \& Evans, C. (2016). The influence of eWOM in social media on consumers' purchase intentions: An extended approach to information adoption. Computers in Human Behavior, 61, 47-55.

Fan, Y., \& Niu, R. H. (2016). To tweet or not to tweet? Exploring the effectiveness of service recovery strategies using social media. International Journal of Operations \& Production Management, 36(9), 1014-1036

Felix, R., Rauschnabel, P. A., \& Hinsch, C. (2017). Elements of strategic social media marketing: A holistic framework. Journal of Business Research, 70, 118-126.

Fidel, R., \& Green, M. (2004). The many faces of accessibility: engineers' perception of information sources. Information Processing \& Management, 40(3), 563-581.

Fisher, D. R., Waggle, J., \& Leifeld, P. (2013). Where does political polarization come from? Locating polarization within the US climate change debate. American Behavioral Scientist, 57(1), 70-92.

Flaxman, S., Goel, S., \& Rao, J. M. (2016). Filter bubbles, echo chambers, and online news consumption. Public Opinion Quarterly, 80(S1), 298-320.

Fletcher, R., \& Nielsen, R. K. (2018). Are people incidentally exposed to news on social media? A comparative analysis. New Media \& Society, 20(7), 2450-2468.

Fu, X. J., Goh, R. S. M., Tong, J. C., Ponnambalam, L., Yin, X. F., Wang, Z. X., \& Lu, S. F. ... (2013, December). Social media for supply chain risk management. In 2013 IEEE International Conference on Industrial Engineering and Engineering Management (pp. 206-210). IEEE

Gallaugher, J., \& Ransbotham, S. (2010). Social media and customer dialog management at Starbucks. MIS Quarterly Executive, 9(4), 197-212.

Garimella, K., De Francisci Morales, G., Gionis, A., \& Mathioudakis, M. (2018). Political discourse on social media: Echo chambers, gatekeepers, and the price of bipartisanship. In Proceedings of the 2018 World Wide Web Conference (pp. 913-922)

Garrett, R. K. (2009). Echo chambers online?: Politically motivated selective exposure among Internet news users. Journal of Computer-Mediated Communication, 14(2), 265-285.

Gates, B. (2020). Responding to Covid-19 - A Once-in-a-Century Pandemic?'. New England Journal of Medicine, 382(18), 1677-1679.

Geschke, D., Lorenz, J., \& Holtz, P. (2019). The triple-filter bubble: Using agent-based modelling to test a meta-theoretical framework for the emergence of filter bubbles and echo chambers. British Journal of Social Psychology, 58(1), 129-149.

Giannakis, M., Dubey, R., Yan, S., Spanaki, K., \& Papadopoulos, T. (2020). Social media and sensemaking patterns in new product development: demystifying the customer sentiment. Annals of Operations Research. https://doi.org/10.1007/ s10479-020-03775-6.

Giannoccaro, I. (2018). Centralized vs. decentralized supply chains: The importance of decision maker's cognitive ability and resistance to change. Industrial Marketing Management, 73, 59-69.

Gillespie, T., Boczkowski, P. J., \& Foot, K. A. (Eds.). (2014). Media technologies: Essays on communication, materiality, and society. MIT Press

Go, E., \& You, K. H. (2016). But not all social media are the same: Analyzing organizations' social media usage patterns. Telematics and Informatics, 33(1), 176-186.
Gomber, P., Kauffman, R. J., Parker, C., \& Weber, B. W. (2018). On the fintech revolution: Interpreting the forces of innovation, disruption, and transformation in financial services. Journal of Management Information Systems, 35(1), 220-265.

Gorwa, R., \& Guilbeault, D. (2020). Unpacking the social media bot: A typology to guide research and policy. Policy \& Internet, 12(2), 225-248.

Grant, S. B. (2016). Classifying emerging knowledge sharing practices and some insights into antecedents to social networking: a case in insurance. Journal of Knowledge Management, 20(5), 898-917.

Guess, A., Nyhan, B., \& Reifler, J. (2018). Selective exposure to misinformation: Evidence from the consumption of fake news during the 2016 US presidential campaign. European Research Council, 9(3), 4.

Gupta, M., Parra, C. M., \& Dennehy, D. (2021). Questioning racial and gender bias in AI-based recommendations: do espoused national cultural values matter? Information Systems Frontiers, 1-17. https://doi.org/10.1007/s10796-021-10156-2.

Gupta, M., Esmaeilzadeh, P., Uz, I., \& Tennant, V. M. (2019). The effects of national cultural values on individuals' intention to participate in peer-to-peer sharing economy. Journal of Business Research, 97, 20-29.

Gupta, M., Uz, I., Esmaeilzadeh, P., Noboa, F., Mahrous, A. A., Kim, E., \& Kulikova, I. (2018). Do cultural norms affect social network behavior inappropriateness? A global study. Journal of Business Research, 85, 10-22.

Han, J., \& Federico, C. M. (2018). The polarizing effect of news framing: Comparing the mediating roles of motivated reasoning, selfstereotyping, and intergroup animus. Journal of Communication, 68(4), 685-711.

Havakhor, T., Soror, A. A., \& Sabherwal, R. (2018). Diffusion of knowledge in social media networks: effects of reputation mechanisms and distribution of knowledge roles. Information Systems Journal, 28(1), 104-141.

He, W., Wang, F. K., \& Akula, V. (2017). Managing extracted knowledge from big social media data for business decision making. Journal of Knowledge Management, 21(2), 275-294.

Huang, H. H., Hsu, J. S. C., \& Ku, C. Y. (2012). Understanding the role of computer-mediated counter-argument in countering confirmation bias. Decision Support Systems, 53(3), 438-447.

Huang, S., Potter, A., \& Eyers, D. (2020). Social media in operations and supply chain management: State-of-the-Art and research directions. International Journal of Production Research, 58(6), 1893-1925.

Hutchens, M. J., Hmielowski, J. D., Beam, M. A., \& Romanova, E. (2021). Trust over Use: Examining the Roles of Media Use and Media Trust on Misperceptions in the 2016 US Presidential Election. Mass Communication and Society, 1-24.

Hyun, K. D., \& Moon, S. J. (2016). Agenda setting in the partisan TV news context: Attribute agenda setting and polarized evaluation of presidential candidates among viewers of NBC, CNN, and Fox News. Journalism \& Mass Communication Quarterly, 93(3), 509-529.

India Today (2021). Fake news on social media leads to vaccine hesitancy in parts of Kolkata. Available at- https://www.indiatoday. in/cities/kolkata/story/fake-news-social-media-vaccine-hesit ancy-kolkata-1810021-2021-06-02. Accessed 10 July 2021

Islam, A. N., Laato, S., Talukder, S., \& Sutinen, E. (2020). Misinformation sharing and social media fatigue during COVID-19: An affordance and cognitive load perspective. Technological Forecasting and Social Change. https://doi.org/10.1016/j.techf ore.2020.120201.

Itzchakov, G., \& Van Harreveld, F. (2018). Feeling torn and fearing rue: Attitude ambivalence and anticipated regret as antecedents 
of biased information seeking. Journal of Experimental Social Psychology, 75, 19-26.

Jacobson, S., Myung, E., \& Johnson, S. L. (2016). Open media or echo chamber: The use of links in audience discussions on the Facebook pages of partisan news organizations. Information, Communication \& Society, 19(7), 875-891.

Jamieson, K. H. (2020). Cyberwar: how Russian hackers and trolls helped elect a president: what we don't, can't, and do know. Oxford University Press

Jaramillo-Dent, D., \& Pérez-Rodríguez, M. A. (2021). \#MigrantCaravan: The border wall and the establishment of otherness on Instagram. New Media \& Society, 23(1), 121-141.

Juris, J. S. (2012). Reflections on\# Occupy Everywhere: Social media, public space, and emerging logics of aggregation. American Ethnologist, 39(2), 259-279.

Kanagarajoo, M. V., Fulford, R., \& Standing, C. (2019). The contribution of social media to project management. International Journal of Productivity and Performance Management, 69(4), 834-872.

Kapoor, K. K., Tamilmani, K., Rana, N. P., Patil, P., Dwivedi, Y. K., \& Nerur, S. (2018). Advances in social media research: Past, present and future. Information Systems Frontiers, 20(3), 531-558.

Kelman, H. C. (2006). Interests, relationships, identities: Three central issues for individuals and groups in negotiating their social environment. Annual Review of Psychology, 57, 1-26.

Kietzmann, J. H., Hermkens, K., McCarthy, I. P., \& Silvestre, B. S. (2011). Social media? Get serious! Understanding the functional building blocks of social media. Business Horizons, 54(3), 241-251.

Kim, Y., \& Kim, Y. (2019). Incivility on Facebook and political polarization. The mediating role of seeking further comments and negative emotion. Computers in Human Behavior, 99, 219-227

Knobloch-Westerwick, S., \& Kleinman, S. B. (2012). Preelection selective exposure: Confirmation bias versus informational utility. Communication Research, 39(2), 170-193.

KPMG (2021). Combating fraud in the time of Covid-19. Available on -https://home.kpmg/in/en/home/insights/2020/05/ combatting-fraud-in-the-time-of-covid-19.html. Accessed 17 July 2021

Laato, S., Islam, A. N., Islam, M. N., \& Whelan, E. (2020). What drives unverified information sharing and cyberchondria during the COVID-19 pandemic? European Journal of Information Systems, 29(3), 288-305.

LATimes (2019). 'Fake news' has killed Nigerians. Can a bill stop the violence? Available at- https://www.latimes.com/ world-nation/story/2019-12-24/la-fg-nigeria-fake-news-bill. Accessed 24 June 2021

Langley, D., Reidy, C., Towey, M., Manisha, \& Dennehy, D. (2021). Developing a machine learning model for predicting social media induced fake news. In Proceedings of The 20th IFIP Conference e-Business, e-Services, and e-Society. 3E 2021, Springer, LNCS 12896, pp. 656-669

Layman, G. C., Carsey, T. M., \& Horowitz, J. M. (2006). Party polarization in American politics: Characteristics, causes, and consequences. Annual Review of Politics Science, 9, 83-110.

Lee, F. L. (2016). Impact of social media on opinion polarization in varying times. Communication and the Public, 1(1), 56-71.

Lee, J., Agrawal, M., \& Rao, H. R. (2015). Message diffusion through social network service: The case of rumor and non-rumor related tweets during Boston bombing 2013. Information Systems Frontiers, 17(5), 997-1005.

Lee, J. K., Choi, J., Kim, C., \& Kim, Y. (2015). Social media, network heterogeneity, and opinion polarization. Journal of Communication, 64(4), 702-722.
Legner, C., Eymann, T., Hess, T., Matt, C., Böhmann, T., Drews, P., \& Ahlemann, F. (2017). Digitalization: opportunity and challenge for the business and information systems engineering community. Business \& Information Systems Engineering, 59(4), 301-308.

Leviston, Z., Walker, I., \& Morwinski, S. (2013). Your opinion on climate change might not be as common as you think. Nature Climate Change, 3(4), 334-337.

Linvill, D. L., \& Warren, P. L. (2020). Troll factories: Manufacturing specialized disinformation on Twitter. Political Communication. https://doi.org/10.1080/10584609.2020.1718257.

Manavalan, E., \& Jayakrishna, K. (2019). A review of Internet of Things (IoT) embedded sustainable supply chain for industry 4.0 requirements. Computers \& Industrial Engineering, 127, 925-953.

Matavire, R., \& Brown, I. (2013). Profiling grounded theory approaches in information systems research. European Journal of Information Systems, 22(1), 119-129.

McKinsey \& Company (2015). Getting a sharper picture of social media's influence. Available athttps://www.mckinsey.com/busin ess-functions/marketing-and-sales/our-insights/getting-a-sharp er-picture-of-social-medias-influence. Accessed 26 June 2021

Mheidly, N., \& Fares, J. (2020). Leveraging media and health communication strategies to overcome the COVID-19 infodemic. Journal of Public Health Policy, 41, 410-420.

Min, H., \& Zhou, G. (2002). Supply chain modeling: past, present and future. Computers \& Industrial Engineering, 43(1-2), 231-249.

Miroudot, S. (2020). Reshaping the policy debate on the implications of COVID-19 for global supply chains. Journal of International Business Policy, 3(4), 430-442.

Mondal, T., Pramanik, P., Bhattacharya, I., Boral, N., \& Ghosh, S. (2018). Analysis and early detection of rumors in a post disaster scenario. Information Systems Frontiers, 20(5), 961-979.

Montalvo, J. G., \& Reynal-Querol, M. (2005). Ethnic polarization, potential conflict, and civil wars. American Economic Review, 95(3), 796-816.

Muckstadt, J. A., Murray, D. H., Rappold, J. A., \& Collins, D. E. (2001). Guidelines for collaborative supply chain system design and operation. Information Systems Frontiers, 3(4), 427-453.

Nabity-Grover, T., Cheung, C. M., \& Thatcher, J. B. (2020). Inside out and outside in: How the COVID-19 pandemic affects selfdisclosure on social media. International Journal of Information Management. https://doi.org/10.1016/j.ijinfomgt.2020.102188.

Naderifar, M., Goli, H., \& Ghaljaie, F. (2017). Snowball sampling: A purposeful method of sampling in qualitative research. Strides in Development of Medical Education, 14(3), 1-6.

Neiman, J. L., Gonzalez, F. J., Wilkinson, K., Smith, K. B., \& Hibbing, J. R. (2016). Speaking different languages or reading from the same script? Word usage of Democratic and Republican politicians. Political Communication, 33(2), 212-240.

Nelson, J. (2017). Using conceptual depth criteria: addressing the challenge of reaching saturation in qualitative research. Qualitative Research, 17(5), 554-570.

Neves, A. R. D. M., Carvalho, Ã. M. G., \& Ralha, C. G. (2014), Agent-based architecture for context-aware and personalized event recommendation. Expert Systems with Applications, 41(2), $563-573$.

Newman, N., Fletcher, R., Kalogeropoulos, A., Levy, A., \& Nielsen, R. (2017). Reuters Institute digital news report 2017. Available at: https://reutersinstitute.politics.ox.ac.uk/sites/default/files/Digit al\%20News\%20Report\%202017\%20web_0.pdf. Retrieved on 22nd Jan 2021

Nikolov, D., Lalmas, M., Flammini, A., \& Menczer, F. (2019). Quantifying biases in online information exposure. Journal of the Association for Information Science and Technology, 70(3), 218-229. 
Noy, C. (2008). Sampling knowledge: the hermeneutics of snowball sampling in qualitative research. International Journal of Social Research Methodology, 11(4), 327-344.

Obar, J. A., Zube, P., \& Lampe, C. (2012). Advocacy 2.0: An analysis of how advocacy groups in the United States perceive and use social media as tools for facilitating civic engagement and collective action. Journal of Information Policy, 2, 1-25.

O'Hara, K., \& Stevens, D. (2015). Echo chambers and online radicalism: Assessing the Internet's complicity in violent extremism. Policy \& Internet, 7(4), 401-422.

O'Leary, D. E. (2011). The use of social media in the supply chain: Survey and extensions. Intelligent Systems in Accounting, Finance and Management, 18(2-3), 121-144.

Orji, I. J., Kusi-Sarpong, S., \& Gupta, H. (2020). The critical success factors of using social media for supply chain social sustainability in the freight logistics industry. International Journal of Production Research, 58(5), 1522-1539.

Osatuyi, B. (2013). Information sharing on social media sites. Computers in Human Behavior, 29(6), 2622-263.

Parra, C., Gupta, M., \& Dennehy, D. (2021). Likelihood of questioning ai-based recommendations due to perceived racial/gender bias. IEEE Transactions on Technology and Society. https://doi.org/ 10.1109/TTS.2021.3120303.

Pagell, M., \& Wu, Z. (2009). Building a more complete theory of sustainable supply chain management using case studies of 10 exemplars. Journal of Supply Chain Management, 45(2), 37-56.

Pariser, E. (2011). The filter bubble: How the new personalized web is changing what we read and how we think. Penguin

Petty, R. E., Briñol, P., \& Priester, J. R. (2009). Mass media attitude change: Implications of the elaboration likelihood model of persuasion. In J. Bryant \& M. B. Oliver (Eds.), Media effects: Advances in theory and research (pp. 125-164). Routledge.

Petty, R. E., Kasmer, J. A., Haugtvedt, C. P., \& Cacioppo, J. T. (1987). Source and message factors in persuasion: A reply to Stiff's critique of the elaboration likelihood model. Communication Monographs, 54, 233-249.

PwC (2021). How fake news has exploited Covid-19. Available athttps://www.pwc.co.uk/issues/crisis-and-resilience/covid-19/ how-fake-news-has-exploited-covid19-cyber.html. Accessed 18 July 2021

Rauniar, R., Rawski, G., Yang, J., \& Johnson, B. (2014). Technology acceptance model (TAM) and social media usage: an empirical study on Facebook. Journal of Enterprise Information Management, 27(1), 6-30.

Reuters (2021). Apple CEO slams social media in Facebook fight. https://www.reuters.com/video/watch/apple-ceo-slams-socialmedia-in-facebook-id724962792?chan=9qsux 198. Accessed 13 Nov 2021.

Ribarsky, W., Wang, D. X., \& Dou, W. (2014). Social media analytics for competitive advantage. Computers \& Graphics, 38, 328-331.

Rim, H., Lee, Y., \& Yoo, S. (2020). Polarized public opinion responding to corporate social advocacy: Social network analysis of boycotters and advocators. Public Relations Review. https://doi.org/ 10.1016/j.pubrev.2019.101869.

Roozenbeek, J., \& van der Linden, S. (2019). The fake news game: actively inoculating against the risk of misinformation. Journal of Risk Research, 22(5), 570-580.

Rousidis, D., Koukaras, P., \& Tjortjis, C. (2020). Social media prediction: a literature review. Multimedia Tools and Applications, 79(9), 6279-6311.

Said, E. W. (2008). Covering Islam: How the Media and the Experts Determine How We See the Rest of the World. Random House.

Sarimveis, H., Patrinos, P., Tarantilis, C. D., \& Kiranoudis, C. T. (2008). Dynamic modeling and control of supply chain systems: A review. Computers \& Operations Research, 35(11), 3530-3561.
Sarkis, J. (2020). Supply chain sustainability: learning from the COVID-19 pandemic. International Journal of Operations \& Production Management, 41(1), 63-73.

Sasahara, K., Chen, W., Peng, H., Ciampaglia, G. L., Flammini, A., \& Menczer, F. (2021). Social influence and unfollowing accelerate the emergence of echo chambers. Journal of Computational Social Science, 4(1), 381-402.

Sasahara, K., Chen, W., Peng, H., Ciampaglia, G. L., Flammini, A., \& Menczer, F. (2020). Social influence and unfollowing accelerate the emergence of echo chambers. Journal of Computational Social Science, 1-22

Schäfer, F., Evert, S., \& Heinrich, P. (2017). Japan's 2014 general election: Political bots, right-wing internet activism, and Prime Minister Shinzō Abe's hidden nationalist agenda. Big Data, 5(4), 294-309.

Schilling, M. A., \& Fang, C. (2014). When hubs forget, lie, and play favorites: Interpersonal network structure, information distortion, and organizational learning. Strategic Management Journal, 35(7), 974-994.

Sestino, A., Prete, M. I., Piper, L., \& Guido, G. (2020). Internet of Things and Big Data as enablers for business digitalization strategies. Technovation. https://doi.org/10.1016/j.technovati on.2020.102173.

Sharif, A. M. (2002). Professional services organizations and the role of consulting in the new economy. Information Systems Management, 19(2), 19-30.

Sharma, A., Adhikary, A., \& Borah, S. B. (2020). Covid-19's impact on supply chain decisions: strategic insights for NASDAQ 100 firms using twitter data. Journal of Business Research, 117, 443-449.

Shearer, E., \& Grieco, E. (2019). Americans are wary of the role social media sites play in delivering the news. Pew Research Center. Available at: https://www.journalism.org/2019/10/02/ americans-are-wary-of-the-role-social-media-sites-play-indelivering-the-news/. Reterived on 22nd January 2021

Shin, J., \& Thorson, K. (2017). Partisan selective sharing: The biased diffusion of fact-checking messages on social media. Journal of Communication, 67(2), 233-255.

Sikder, O., Smith, R. E., Vivo, P., \& Livan, G. (2020). A minimalistic model of bias, polarization and misinformation in social networks. Scientific Reports, 10(1), 1-11.

Singh, A., Shukla, N., \& Mishra, N. (2018). Social media data analytics to improve supply chain management in food industries. Transportation Research Part E: Logistics and Transportation Review, 114, 398-415.

Singh, J. P., Kumar, A., Rana, N. P., \& Dwivedi, Y. K. (2020). Attention-based LSTM network for rumor veracity estimation of tweets. Information Systems Frontiers. https://doi.org/10.1007/ s10796-020-10040-5.

Sodhi, M. S., \& Tang, C. S. (2019). Research opportunities in supply chain transparency. Production and Operations Management, 28(12), 2946-2959.

Spanaki, K., Gürgüç, Z., Mulligan, C., \& Lupu, E. (2019). Organizational cloud security and control: a proactive approach. Information Technology \& People, 32(3), 516-537.

Spohr, D. (2017). Fake news and ideological polarization: Filter bubbles and selective exposure on social media. Business Information Review, 34(3), 150-160.

Stake, R. E. (2000). The art of case study research. Sage.

Stepan, T., Morawski, J. M., Dick, S., \& Miller, J. (2016). Incorporating spatial, temporal, and social context in recommendations for location-based social networks. IEEE Transactions on Computational Social Systems, 3(4), 164-175.

Stieglitz, S., \& Dang-Xuan, L. (2013). Social media and political communication: a social media analytics framework. Social Network Analysis and Mining, 3(4), 1277-1291. 
Strauss, A., \& Corbin, J. M. (1997). Grounded theory in practice. Sage. Stroud, N. J. (2008). Media use and political predispositions: Revisiting the concept of selective exposure. Political Behavior, 30(3), 341-366.

Stuart, I., McCutcheon, D., Handfield, R., McLachlin, R., \& Samson, D. (2002). Effective case research in operations management: a process perspective. Journal of Operations Management, 20(5), 419-433.

Susarla, A., Oh, J. H., \& Tan, Y. (2012). Social networks and the diffusion of user-generated content: Evidence from YouTube. Information Systems Research, 23(1), 23-41.

Teo, T. S., Srivastava, S. C., \& Jiang, L. (2008). Trust and electronic government success: An empirical study. Journal of Management Information Systems, 25(3), 99-132.

Thatcher, J. B., Wright, R. T., Sun, H., Zagenczyk, T. J., \& Klein, R. (2018). Mindfulness in information technology use: definitions, distinctions, and a new measure. MIS Quarterly, 42(3), 831-847.

Tim, Y., Cui, L., \& Sheng, Z. (2021). Digital resilience: How rural communities leapfrogged into sustainable development. Information Systems Journal. https://doi.org/10.1111/isj.12312.

Tim, Y., Pan, S. L., Bahri, S., \& Fauzi, A. (2018). Digitally enabled affordances for community-driven environmental movement in rural Malaysia. Information Systems Journal, 28(1), 48-75.

Toubiana, M., \& Zietsma, C. (2017). The message is on the wall? Emotions, social media and the dynamics ofinstitutional complexity. Academy of Management Journal, 60(3), 922-953.

Tran, T., Valecha, R., Rad, P., \& Rao, H. R. (2020). An investigation of misinformation harms related to social media during two humanitarian crises. Information Systems Frontiers. https://doi. org/10.1007/s10796-020-10088-3.

van Strien, J. L., Kammerer, Y., Brand-Gruwel, S., \& Boshuizen, H. P. (2016). How attitude strength biases information processing and evaluation on the web? Computers in Human Behavior, 60, 245-252.

Verma, S., \& Gustafsson, A. (2020). Investigating the emerging COVID-19 research trends in the field of business and management: A bibliometric analysis approach. Journal of Business Research, 118, 253-261.

Vishwanath, A. (2015). Diffusion of deception in social media: Social contagion effects and its antecedents. Information Systems Frontiers, 17(6), 1353-1367.

Walsham, G. (1993). IS strategy and implementation: a case study of a building society. ACM SIGOIS Bulletin, 14(2), 13-16.

Wang, X. H., Fang, Y., Qureshi, I., \& Janssen, O. (2015). Understanding employee innovative behavior: Integrating the social network and leader-member exchange perspectives. Journal of Organizational Behavior, 36(3), 403-420.

Weckler, A. (2021). Apple's Tim Cook accuses Facebook of creating chaos and hate. https://www.independent.ie/business/apples-timcook-accuses-facebook-of-creating-chaos-and-hate-40023709. html. Retrieved on 29th Jan 2021

Westerwick, A., Johnson, B. K., \& Knobloch-Westerwick, S. (2017). Confirmation biases in selective exposure to political online information: Source bias vs. content bias. Communication Monographs, 84(3), 343-364

Winter, S. J., \& Butler, B. S. (2011). Creating bigger problems: grand challenges as boundary objects and the legitimacy of the information systems field. Journal of Information Technology, 26(2), 99-108.

World Economic Forum (2018). Digital wildfires Report. https://repor ts.weforum.org/global-risks-2018/digital-wildfires/. Retrieved on 29th Jan 2021

Wu, L., Morstatter, F., Carley, K. M., \& Liu, H. (2019). Misinformation in social media: definition, manipulation, and detection. $A C M$ SIGKDD Explorations Newsletter, 21(2), 80-90.
Wu, Y. L., \& Li, E. Y. (2018). Marketing mix, customer value, and customer loyalty in social commerce. Internet Research, 28(1), 74-104.

Wuebben, D. (2016). Getting likes, going viral, and the intersections between popularity metrics and digital composition. Computers and Composition, 42, 66-79.

Xie, K., \& Lee, Y. J. (2015). Social media and brand purchase: Quantifying the effects of exposures to earned and owned social media activities in a two-stage decision making model. Journal of Management Information Systems, 32(2), 204-238.

Yarchi, M., Baden, C., \& Kligler-Vilenchik, N. (2020). Political polarization on the digital sphere: A cross-platform, over-time analysis of interactional, positional, and affective polarization on social media. Political Communication. https://doi.org/10.1080/10584 609.2020 .1785067$.

Yin, R. K. (2002). Case study research: Design and methods. SAGE.

Zadeh, A. H., \& Sharda, R. (2014). Modeling brand post popularity dynamics in online social networks. Decision Support Systems, 65, 59-68.

Zamani, E. D., \& Pouloudi, N. (2021). Shared mental models and perceived proximity: a comparative case study. Information Technology \& People. https://doi.org/10.1108/ITP-02-2020-0072.

Zamani, E. D., Pouloudi, N., Giaglis, G. M., \& Wareham, J. (2020). Appropriating information technology artefacts through trial and error: the case of the tablet. Information Systems Frontiers. https://doi.org/10.1007/s10796-020-10067-8.

Zhang, M., Guo, L., Hu, M., \& Liu, W. (2017). Influence of customer engagement with company social networks on stickiness: Mediating effect of customer value creation. International Journal of Information Management, 37(3), 229-240.

Zhao, H., Fu, S., \& Chen, X. (2020). Promoting users' intention to share online health articles on social media: The role of confirmation bias. Information Processing \& Management, 57(6), 102354. https://doi.org/10.1016/j.ipm.2020.102354.

Publisher's Note Springer Nature remains neutral with regard to jurisdictional claims in published maps and institutional affiliations.

Sachin Modgil (Ph.D.) is an Assistant Professor in International Management Institute Kolkata in India. He has pursued his $\mathrm{PhD}$ from NITIE, Mumbai, India in the domain of technology and operations management. His areas of interest include big data, artificial intelligence, supply chain management, sustainable operations and production management, lean management, operations, and strategy control. He has more than 9 years of experience including industry and academia. He has conducted several MDPs and FDPs in operations management domain and has published research papers in leading academic journals.

Rohit Kumar Singh (Ph.D.) is an Associate Professor in International Management Institute Kolkata in India. He pursued his $\mathrm{PhD}$ in the domain of supply chain management from Indian Institute of Information Technology, Gwalior. He is actively involved in research and has published papers in journals of international repute and presented papers and chaired sessions at international and national conferences. He has also been the convener and organizing secretary of two international conferences in operations and supply chain management.

Shivam Gupta (Ph.D.) is a Professor at NEOMA Business School, France with a demonstrated history of working in the higher education industry. Skilled in Statistics, Cloud Computing, Big Data Analytics, Artificial Intelligence and Sustainability. Strong education professional 
with a Doctor of Philosophy $(\mathrm{PhD})$ focused on Cloud Computing and Operations Management from Indian Institute of Technology (IIT) Kanpur. Followed by $\mathrm{PhD}$, postdoctoral research was pursued at Freie Universität Berlin and SUSTech, China. He has completed HDR from University of Montpellier, France. He has published several research papers in reputed journals and has been the recipient of the International Young Scientist Award by the National Natural Science Foundation of China (NSFC) in 2017 and winner of the 2017 Emerald South Asia LIS award.
Denis Dennehy (Ph.D.) is the Director of the master's in business Analytics and funded investigator with Lero I The Irish Software Research Centre at NUI Galway, Ireland. His research examines the mediating role of digital technologies and analytics in the context of information systems, and its implications for people, organisations, and society. This research has been published in leading journals including European Journal of Operational Research,International Journal of Operations and Production Management; Information Systems Frontiers,International Journal of Production Research, Information \& Management, IT \& People, and IEEE.He is a Senior Editor ofInformation Technology \& People, chaired IFIP I3E2021 conference and edited numerous special issues. 